\title{
Historický a očekávaný vývoj srážkoodtokových charakteristik na okraji Prahy
}

\section{LUDĚK STROUHAL, PETRA ŠUHÁJKOVÁ, ONDŘEJ MASÁK}

\author{
Klíčová slova: povodňové odtoky - dopady urbanizace - historický vývoj - změny klimatu - srážkoodtokový model
}

\section{SOUHRN}

Tento príspěvek prezentuje studii vývoje srážkoodtokových charakteristik v šesti povodích na okraji Prahy od roku 1920 s výhledem do roku 2050. Kvůli neexistujícímu dlouhodobému monitoringu bylo hodnocení provedeno prostřednictvím srážkoodtokového modelování v prostředí HEC-HMS. Klícovým vstupem pro hydrologické modely povodí byly mapy půdního pokryvu. Ty byly pro každý z pěti hodnocených historických horizontů vytvořeny částečnou digitalizací, analýzou a kompilací několika dostupných historických mapových podkladů. Navrženy byly i dva budoucí scénáře očekávaného vývoje. Oproti očekávání nebyl na pilotních povodích zjištěn monotónní nárůst čísel odtokových křivek $(\mathrm{CN}) \vee$ průběhu hodnoceného období. Modelované historické odtoky vykazovaly nejednoznačný vývoj s rostoucím, ale i klesajícím charakterem. Jako klíčový faktor s jednoznačným vývojem byl identifikován podíl nepropustných ploch, zejména jeho část prímo napojená na hydrografickou sít. Jejich podíl není v současnosti možné stanovit zejména kvůli chybějícím detailním mapovým podkladům. Analýza kulminačních průtoků poukázala na značné nejistoty plynoucí z variability časového rozdělení intenzit vydatných srážek. Zjištěný rozsah kulminací je srovnatelný se signálem změny srážkových úhrnů vlivem klimatické změny. Vliv budoucího vývoje urbanizace byl ve studii prokázán zejména $\checkmark$ povodích $s$ dosud nevyčerpaným potenciálem pro další zástavbu, predikované kulminační odtoky oproti současnosti vždy rostou, avšak ne na všech povodích přesahují predikce zjištěná historická maxima. Rozdíly mezi budoucími scénáři vývoje slábnou s rostoucí extremitou prričinných srážek. Model Vinořského potoka poukázal i na možnost kompenzovat dopad klimatických změn vhodným využitím a managementem volné krajiny. Zjištěný vývoj kulminačních odtoků je specifický pro každé pilotní povodí a nelze jej zobecnit a jednoznačně přenést do dalších povodí, což zdưrazňuje potřebu dalšího detailního mapování a individuálního př́istupu při hodnocení daného povodí.

\section{ÚVOD}

Při osvojování původně prírodní krajiny člověkem - urbanizaci - docházelo od počátku ke konfliktům lidských sídel s extrémními hydrologickými projevy, jako jsou povodně. Dnes se jeví jako samozřejmé, že jsou stavby umistovány s ohledem na možné rozlivy významných vodních toků. Ty jsou již dlouhou dobu monitorovány, jejich hydrologický režim je statisticky popsán a pravidelně aktualizován a prvky protipovodňové ochrany navrženy s ohledem na zvolenou pravděpodobnost výskytu vypočtené úrovně hladiny. Na drobných vodních tocích je však situace složitější - zpravidla zde neprobíhá trvalý monitoring hydrologického režimu, návrhové stavy či průtoky je tedy nutné odvozovat neprímo. V posledních desetiletích navíc sídla ukrajuji stále větší část volné krajiny a hydrologické charakteristiky povodí drobných vodních toků se dramaticky mění. Tyto změny spolu s probíhající proměnou klimatických podmínek pritahují více pozornosti obyvatelstva i státní správy k extrémním hydrologickým jevưm i na těchto malých tocích.

Posouzení historického a budoucího vývoje odtokového režimu v malých okrajových povodích kolem hlavního města Prahy bylo jedním z úkolů projektu „Analýza adaptačních opatření ke zmírnění dopadů změny klimatu a urbanizace na vodní režim v oblasti vnější Prahy", řešeného v rámci Operačního programu Praha - pól růstu ČR. Projekt se záměrně vyhýbal zcela zastavěné vnitřní části Prahy a jejímu nejvýraznějšímu vodnímu prvku - řece Vltavě. Místo toho obrátil pozornost na 57 povodí IV. řádu zasahujících okraj území hlavního města Prahy (HMP), kde Ize v príštích desetiletích očekávat další rozvoj zástavby. V detailním měřítku pak bylo hodnoceno šest pilotních povodí: Motolského, Dalejského, Kopaninského, Lipanského, Drahanského a Vinořského potoka. Tento príspěvek prezentuje metodiku a dosažené výsledky analýzy extrémních odtokových charakteristik na zmíněných šesti pilotních povodích. Hodnocen byl historický vývoj urbanizace a její dopad na extrémní odtoky od roku 1920 po současnost a výhled vývoje do roku 2050.

\section{METODIKA}

Hydrologický režim drobných vodních toků je zřídka kontinuálně monitorován, což je bohužel i prípad tokư na území HMP. Systematicky jsou sledovány pouze průtoky na tocích Botiče a Rokytky, jejichž povodí je mezi povodími IV. rádu na území HMP největší a v mnoha ohledech se od ostatních liší. Pro odvození povodňových charakteristik v zájmových povodích tak není možné využít prímé statistické vyhodnocení ani metodu analogonu. Jediným nástrojem tak zůstává hydrologické modelování. Standardní postup této metody tvoří:

— volba konceptuálního modelu tvorby odtoku

- sestavení modelu ve vhodném výpočetním nástroji

- kalibrace a validace modelu na pozorovaných událostech (pokud jsou dostupné, v opačném prípadě volba vhodné sady parametrů)

- definice zátěžových stavů / výpočetních scénářů

- posouzení nejistot

Již od počátku bylo zřejmé, že plánované hodnocení bude vyžadovat výpočty podle většího počtu scénárư, podkladová data budou zejména u historických scénářu hrubá a orientační a dosáhnout optimální kalibrace modelů bude obtížné. Tyto předpoklady implikovaly potřebu dostatečně robustního modelu, který by umožnil rychlé výpočty a zohlednění všech požadovaných proměnných bez zanášení výpočtů dodatečnými nejistotami, např. s ohledem na velké množství vstupních parametrů nebo vnitřních proměnných. Zvolena proto 


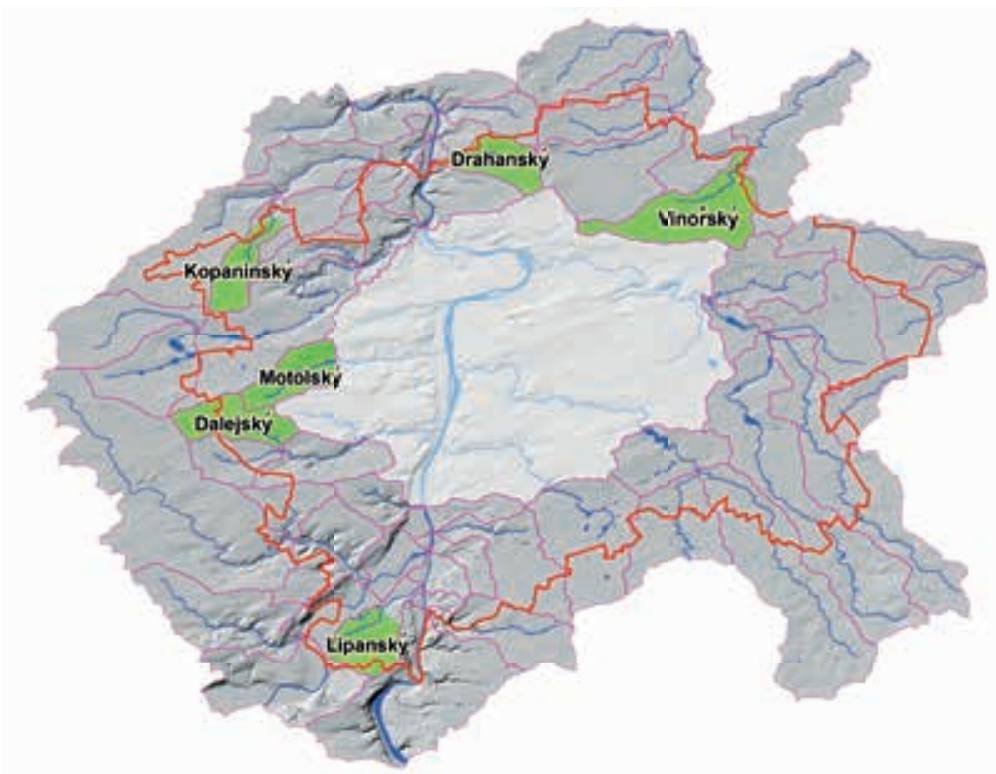

Obr. 1. Prstenec povodí IV. rádu na obvodu HMP a 6 pilotních povodí

Fig. 1. A belt of IV. order catchments on the outskirts of Prague and 6 study catchments

byla kombinace jednoduchých konceptuálních modelů: pro výpočet efektivní srážky zavedená metoda SCS-CN [1] v kombinaci s jednotkovým hydrogramem [2] v jednoparametrické variantě dle SCS [3]. Výpočty byly prováděny ve volně dostupném hydrologickém softwaru HEC-HMS [4].

Zvolená metoda SCS-CN vyžaduje jako základní vstupy informace o zátěžové srážce (povinně úhrn, volitelně i průběh intenzit), hydrologických vlastnostech půd a charakteru půdního pokryvu. Klíčovým a zásadně omezujícím vstupem byly pro celou studii informace o půdním pokryvu a jejich dostupnost pro historická období. Takové datové podklady existují pouze v roztroušené, nekompletní a prevážně rastrové podobě, což znamenalo nutnost ruční digitalizace vybraných mapových podkladů. Provést ji u všech 57 povodí IV. rádu na obvodu HMP bylo mimo možnosti projektu, proto se tato studie soustředila jen na šest pilotních povodí, respektive jejich části vymezené měrnými profily zř́zenými řešitelským týmem. Na obr. 1 jsou zobrazena povodí IV. rádu na území HMP a zvýrazněna pilotní povodí Motolského, Dalejského, Kopaninského, Lipanského, Drahanského a Vinořského potoka. Specifika těchto povodí budou uvedena $v$ části věnované verifikaci modelů, které předchází popis odvození vstupů a struktury modelu.

\section{MAPY PU゚DNÍHO POKRYVU PRO OBDOBÍ 1920-2050}

Pro korektní hydrologické posouzení postupu urbanizace bylo nutné sestavit sadu konzistentních vektorových map vycházejících z kvalitativně rovnocenných podkladů. Jako jediný vektorizovaný podklad o historickém vývoji vnějšího osídlení Prahy byly využity unikátní vrstvy Vývoj zástavby v Praze zpracované na IPR a dostupné prostřednictvím WMS na www.geoportalpraha.cz. Veřejně je prezentován pouze souhrnný rozsah zástavby v časových horizontech 1840, 1880, 1920, 1950, 1970, 1990 a 2010, jak ukazuje obr. 2. Originální datové vrstvy však obsahují i atributy o struktuře zástavby čítající přes 20 urbanistických kategorií, jako je např. Rostlá zástavba venkovského typu, Kompaktní monobloky nebo Drobná rozptýlená zástavba.

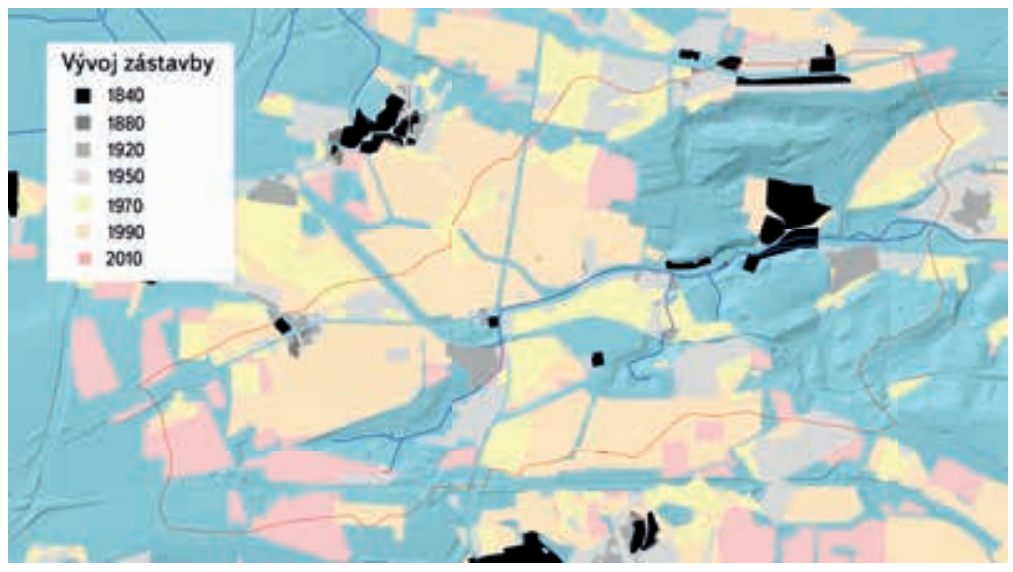

Obr. 2. Historický vývoj města v horní části povodí Motolského potoka dle IPR

Fig. 2. Historic extents of built-up area in the upper part of Motolsky creek catchment, according to IPR

Jakkoli se jedná o velmi cenný datový zdroj, jeho využití pro odvození hydrologických charakteristik komplikovalo několik nedostatků spojených bud' s nedokonalostí jeho zpracování, nebo samotnou povahou jeho účelu:

- Nekonzistentní topologie napríčč časovými horizonty. Jednotlivé polygony zachycující v sousedních časových horizontech totožný stavební objekt či komplex nemají totožné hranice, což komplikuje posouzení časového vývoje kategorizace dané urbanistické jednotky. Při přípravě a čištění finálních vrstev tak byly posuzovány pouze plošně významné překryvy či nedokryvy o velikosti v řádu stovek metrů čtverečních.

- Nekonzistentní kategorizace napríč časovými horizonty. Po zanedbání nevýznamných topologických nepřesností byla prováděna kontrola změn kategorizace polygonů zástavby. Pro hodnocení byly využity historické letecké snímky a ortofotomapy dostupné rovněž na pražském geoportálu. V řadě prípadů se jednalo o skutečně zaniklé nebo transformované objekty (vodní plochy, zastaralé provozy...). Nezřídka však byly nalezeny i náhodné odchylky v kategorizaci v jednom z časových období, způsobené bud' nejasnou metodikou, nebo odlišným subjektivním hodnocením daného zpracovatele při digitalizaci nad historickými mapami. Např. ve vrstvě pro rok 1920 byla součástí polygonů Rostlé venkovské zástavby i humna či sad, zatímco od roku 1950 už byly tyto polygony omezeny pouze na obytná a hospodářská stavení a nejbližší přilehlé zahrady. Tyto nekonzistence byly kvưli své značné variabilitě korigovány manuálně a individuálně jedním zpracovatelem.

- Omezené pokrytí extravilánu a pilotních povodí. Jak Ize usoudit z obr. 2, mapy vývoje města zahrnují jenom zastavěné území. Při detailním pohledu však nalezneme několik kategorií kulturní krajiny, jako jsou Komponované plochy veřejné zeleně nebo Komponované vyhrazené zahrady, jejichž zastoupení v mapových vrstvách je značně kvantitativně i kvalitativně proměnlivé V souhrnu mapy pokrývají jen menši plochu hodnocených území od 3,3 \% v roce 1880 po 36 \% v roce 2012, celý vývoj ukazuje první hodnota uvedená v tab. 1. Z hodnot v závorce lze získat představu o rozsahu zastavěného území $\checkmark$ řešených povodích, číla vznikla po odečtení krajinných kategorií. Po zběžné konfrontaci těchto kategorií s historickými leteckými snímky bylo rozhodnuto o jejich vyloučení z podkladových vrstev kvůli značným rozdílům v charakteru pokryvu uvnitř každé z kategorií. Zbytek plošného rozsahu mapových vrstev - extravilán a části povodí za hranicemi HMP, kam mapy Vývoje města nedosahuji - byl následně ručně digitalizován nad leteckými snímky pro období 1950-2012. Pro dotvoření mapy pokryvu k roku 1920 byly využity nejstarší letecké snímky (z roku 1936), Výškopisný plán HMP a okolí z roku 1920 a Císařské otisky map stabilního katastru. Mapa pokryvu z tohoto období je zatižena ještě vyšší mírou nejistot než ostatní časové horizonty, zejména kvůli obtížnému rozlišení orné pưdy od pastviny či ladem ležící půdy. Časový horizont 1880 byl pro nedostatek podkladů o pokryvu z hodnocení zcela vyřazen. 
Tab. 1. Pokrytí pilotních povodímapami Vývoje města, resp. rozsah zastavěného území (hodnoty v závorce)

Tab. 1. Percentage of study catchments captured by City development maps. Extent of built-up area in brackets

\begin{tabular}{lllllll} 
Referenční rok & 1880 & 1920 & 1950 & 1970 & 1990 & 2012 \\
\hline Pokrytí & & & & & & \\
pilotních & 3,3 & 6,1 & 20 & 30 & 39 & 36 \\
povodí (\%) & $(2,6)$ & $(5,4)$ & $(16)$ & $(26)$ & $(34)$ & $(36)$
\end{tabular}

- Přiliš vysoký počet kategorií zástavby. Pro hydrologické hodnocení území je přes dvacet urbanistických kategorií nadbytečný počet. Již bylo zmíněno vyřazení celkem tři kategorií kulturní krajiny. Díky poloze pilotních povodí na okraji HMP byly i některé kategorie zástavby obsaženy jen okrajově. Ty, jež neměly v některém z časových horizontů celkovou rozlohu alespoň 10 ha, byly na základě podobnosti (charakteru staveb a odhadu podílu nepropustných ploch) překlasifikovány na jednu z četnějších kategorií, prípadně při malé velikosti rozloženy na elementární kategorie Budova a Travní porost.

Pro posouzení dopadu budoucího vývoje města byly vytvořeny dvě mapy odhadovaného půdního pokryvu:

- Mapa pokryvu pro normální vývoj území (scénář N). Zastavěno bude 100 \% území v současnosti označeného v územních plánech jako zastavitelné. Pro kategorizaci zástavby byly v těchto územích vytvořeny nové třídy vycházející z aktuálně platného Plánu využití ploch a funkčního využití území (PVP-FVú).

- Mapa pokryvu pro agresivní vývoj území (scénář A). Uvažováno bylo prolomení hranic zastavitelného území do vzdálenosti $250 \mathrm{~m}$ od existující zástavby ze scénáře N, kategorizace těchto ploch proběhla na základě územních souvislostí - např. úzké pásy mezi frekventovanými komunikacemi byly uvažovány jako zatravněné, plochy vhodné pro zástavbu přejaly kategorii od sousedních ploch.

\section{HYDROLOGICKÉ CHARAKTERISTIKY TŘÍD PŮDNIIHO POKRYVU}

Po zmapování vývoje půdního pokryvu od roku 1920 a jeho extrapolaci k období 2050 bylo nutné definovat hydrologické charakteristiky každé ze zastoupených tříd, prípadně zohlednit jejich proměnlivost v čase. Určováno bylo číslo odtokové křivky CN2 pro průměrné vláhové podmínky (dále jen CN) a procentuální podíl nepropustných ploch (dále značeno IMP). Obě charakteristiky byly získány prostorovou analýzou detailní digitální mapy půdního pokryvu odvozené ze ZABAGED (k roku 2016) a dalších zdrojů, která byla vytvořena speciálně pro účely tohoto projektu. Volba tvorby vlastního mapového podkladu byla dána neexistencí dostatečně podrobné polohopisné mapy s takovými kategoriemi, které by bylo možné jednoduše kvantifikovat z hlediska hydrologického chování. Na obr. 3 je ilustrován príklad, kdy i nejpřesnější vektorový polohopisný podklad ZABAGED selhává v korektním zachycení rozsahu nepropustných povrchů a zelených ploch. To je dáno prílišnou obecností některých kategorií (Ostatní plochy v sídlech, Orná půda a ostatní neurčené plochy...), případně chybějící atributovou informací o skutečné šírce liniových objektů (ulice, silnice). Pro vytvoření základního bezešvého podkladu z objektů ZABAGED byl využit volně dostupný nástroj pro ArcGIS, který vypracoval Devátý [5]. Protože byl nástroj primárně určen pro hydrologicky-erozní klasifikaci extravilánu, bylo nutné v intravilánu provést následné poloautomatické zpřesnění nad leteckým snímkem - např. začlenění šiřkky ulic a komunikací z datových vrstev IPR, řezání a klasifikace plošně významných polygonů na křižení silničních okruhů, sídlištních parkovištích aj.

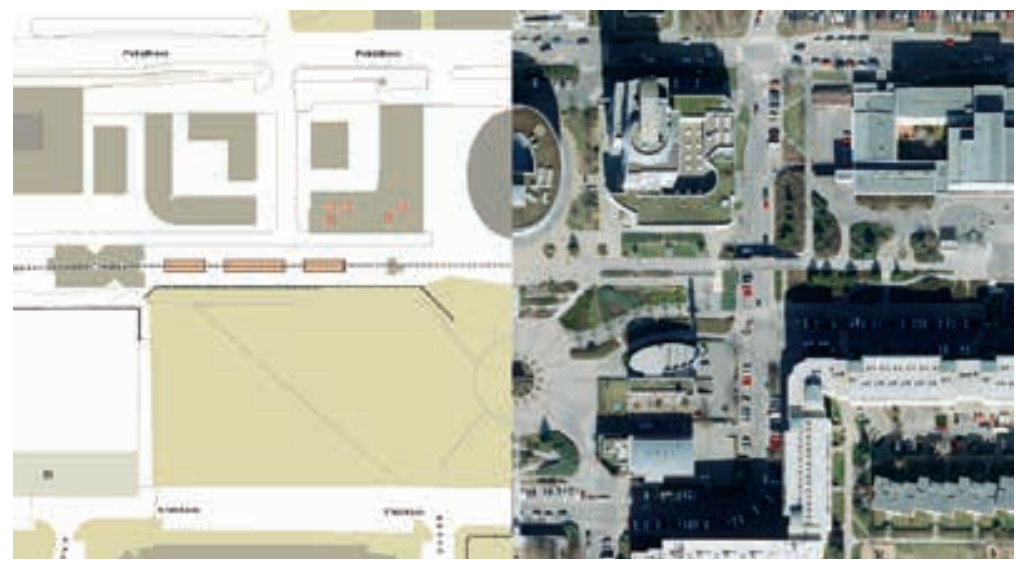

Obr. 3. Př́klad nepřesného zachycení nepropustných povrchů v Základní mapě dle ZABAGED (ČÚZK)

Fig. 3. Illustration of badly captured impervious areas in so called Basic map derived from ZABAGED

Po zpřesnění polohopisu byla zjednodušena klasifikace převedením minoritních nebo nejasných kategorií (zemědělské areály, vodohospodářské stavby aj.) na charakterem nejbližší četnější třídu, prípadně rozložením polygonů na elementární objekty (budova, travní porost, komunikace aj.). Výsledná detailní mapa půdního pokryvu (DMPP) čítá devět kategorií, které již lze velmi dobře charakterizovat z hlediska hydrologického chování a je možné dobře identifikovat jejich ekvivalent v originální tabulce $\mathrm{CN}$ hodnot ( $v$ závorce uvedeno, kde by to mohlo být nejednoznačné):

- Lesy; Nelesní stromová a krovištní vegetace (Křoviny s travním podrostem)

- Sidelnívegetace (Sídelnízeleň - travnaté plochy, parky, golfová hřistě, hřbitovy aj.)

- Vodníplochy a toky

- Odkrytá puida (Nově urbanizované plochy)

- Trvalé travní porosty (Sídelnízeleň, dobré hydrol. podmínky)

- Ornápuida (Úhor)

- Obytné areály - Budovy (Nepropustné plochy)

- Dopravní linie a plochy (kombinace Komunikace nezpevněná a Komunikace dlážděná s obrubníky, proměnlivý podíl dle časového horizontu)

Podíl jednotlivých tříd byl analyzován po protnutí s vrstvou urbanistických kategorií map pưdního pokryvu z predchozí části řešení. Analyzováno bylo zastoupení zvlášt pro každé pilotní povodí, neboť některé urbanistické kategorie byly shledány jako nestejnorodé napríč povodími, respektive městskými částmi. Př́klad takových rozdílů ilustruje graf na obr. 4, patrný je zejména rozdíl $\checkmark$ zastoupení Dopravních linií a ploch a Sídelní vegetace $v$ urbanistické kategorii A1 - kompaktní areály ve třech pilotních povodích, v nichž se daná urbanistická kategorie nachází.

Řešením popsaných nehomogenit bylo rozdělení čtyř problematických urbanistických kategorií na dvě podkategorie a přiřazení specifických podílů tříd půdního pokryvu. Konkrétně se jedná o třídy: O2 - Otevrené sdružená zástavba; V2 - Volné monobloky; A1 - Areály kompaktní a DR - Drobná rozptýlená zástavba. Speciálním prípadem byla třída A2 - rozvolněné areály, která se ukázala jako vysoce variabilní i v rámci jednoho povodí/městské části. Všechny polygony této třídy s relativně vysokým plošným zastoupením (10 \% v roce 2012) byly individuálně zařazeny do jedné z podtříd podle podílu nepropustných ploch na základě expertního odhadu nad leteckým snímkem. Všechny ostatní kategorie byly uvažovány za shodně strukturované napříc všemi pilotními povodími.

Posledním krokem pro stanovení hydrologických charakteristik území bylo mapování hodnot IMP a CN na kategorie DMPP a následně urbanistické kategorie Mapy půdního pokryvu. Pro stanovení CN byly kategorie DMPP ztotožněny 
Struktura půdního pokryvu v kategorii A1

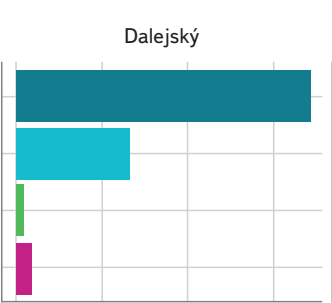

Lipanský

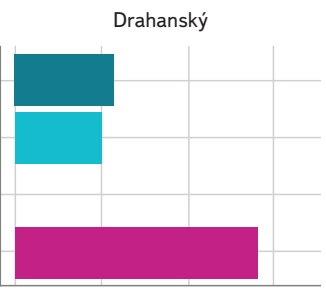

Motolský
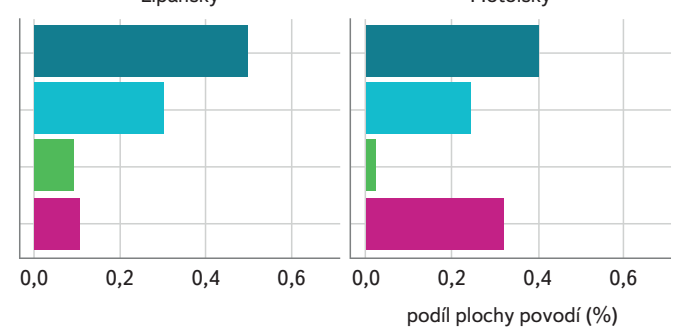

podíl plochy povodí (\%)

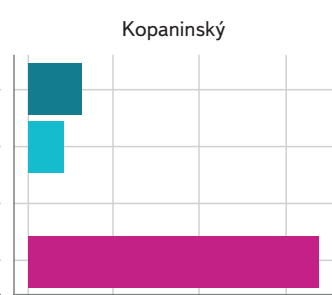

Vinořský

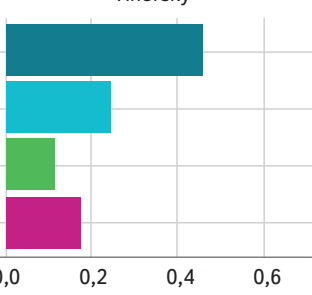

Dopravní linie plochy, areály

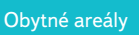

TTP

Sídelní vegetace

Obr. 4. Zastoupení detailních tříd pưdního pokryvu v rámci urbanistické kategorie A1 (areály kompaktní) $\vee$ pilotních povodích

Fig. 4. Detailed land cover classes percentages within the A1 urban category (compact facilities) by study catchments

s nejbližší kategorií land-use dle originální metodiky [1]. V případě komunikací a sídelní vegetace byla navíc uvažována proměnlivost v čase. Pro rok 1920 bylo uvažováno 80 \% komunikací nezpevněných, tento podíl se postupně snižoval až na 10 \% v letech 1990 a 2012. Rovněž sídelní vegetace v rámci urbanistické kategorie V1 - volná sídlištní zástavba byla uvažována jako časově proměnná, nebot’ se jedná většinou o nové sídelní celky budované od 70. let 20. století, kde došlo k postupnému rozvoji travnatých i parkových úprav. Př́slušné hodnoty IMP a CN byly prířazeny $k$ třídám DMPP a následně určeny jejich průměry na základě podílư tříd v rámci každé urbanistické kategorie. Tyto hodnoty pak byly přiřazeny polygonům Map půdního pokryvu individuálně pro roky 1920-2012 a se zohledněním specifik jednotlivých povodí.
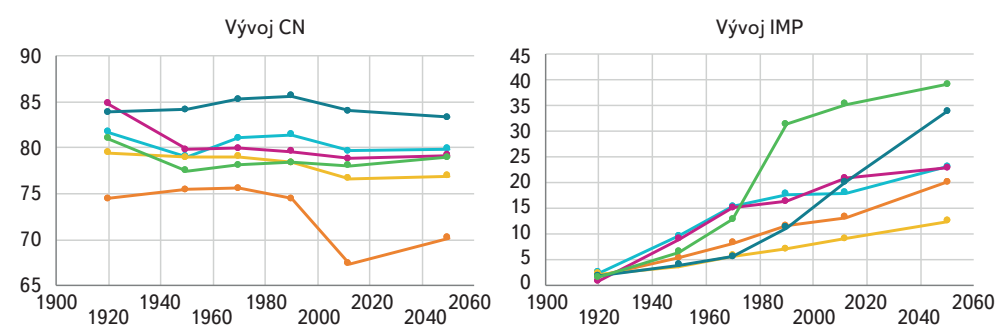

Vinořský

Lipanský

Kopaninský

Drahansky

Dalejský

Motolský

Obr. 5. Vývoj průměrných hodnot CN (vlevo) a procentuálního podílu nepropustných ploch IMP (vpravo) v pilotních povodích

Fig. 5. Historical and projected values of CN (left) and total impervious areas percentage (right) in the study catchments

Analogický postup byl použit pro mapování hodnot CN a IMP na předpokládané nové sídelní celky v rámci budoucích scénářu půdního pokryvu pro rok 2050. Z vektorových vrstev byly následně odvozeny rastrové mapy nepropustných ploch a po kombinaci s vrstvou hydrologických skupin půd (popsáno $\checkmark$ další sekci) mapy detailního rozložení CN. Vývoj průměrných hodnot CN a IMP pro jednotlivá povodí ukazují grafy na obr. 5. Poměrně překvapující je fakt, že změny hodnot CN nejsou dle očekávání monotónně rostoucí, naopak

na každém povodí lze nalézt alespoň v části křivky trend klesající. To je způsobeno skutečností, že $v$ řešeném území postupovala suburbanizace v naprosté většině na úkor orné půdy. $V$ této studii nebyla $k$ dispozici historická agronomická data, a proto byl na orné půdě jednotně uvažován úhor, pro nějž není CN př́iznivější (nižší) než pro některé typy vzniklé zástavby - např. rodinné domky se zahradami. Pokles $v$ CN Ize na některých povodích pozorovat dokonce i pro odhadovaný horizont roku 2050, což by bez započtení přimo napojených nepropustných ploch do modelu vedlo k poklesu simulovaných odtoků a pozitivnímu hodnocení vlivu urbanizace na hydrologický režim povodí, tedy ke zjevně chybnému závěru. Zohlednění podílu IMP je tedy nezbytné. Graf na obr. 5 vpravo ukazuje na rozdíl od CN již jednoznačný nárůst podílu nepropustných ploch ve všech pilotních povodích.

\section{HYDROLOGICKÉ CHARAKTERISTIKY PU゚D}

Aplikace metody SCS-CN vyžaduje informace o tzv. hydrologické skupině pưdy (HSP) [6]. Jedná se o kvalitativní charakteristiku popisující infiltrační schopnost půdy a dostupný retenční prostor, půdy přitom rozřazuje do čtyř tříd A-D. V České republice přetrvává problém dvojkolejnosti metod stanovení HSP na zemědělské a lesní půdě. Zemědělské půdy jsou v tomto směru více probádané, HSP se tradičně určuje na základě převodníku [7] z hlavní půdní jednotky (HPJ), části kódu BPEJ. Stanovit HSP na lesních půdách se u nás poprvé pokusila metodika Janderkové [8] ve spolupráci s pracemi Macků [9] na základě převodníků a map Lesních typů. Tento počin se snad z důvodu slabé dokumentace a nedostatků metodiky prakticky nedostal do povědomí odborné veřejnosti, a v nejmladší publikované mapě HSP [10] je tak pro lesní půdy použito pouze orientační hodnocení na základě pưdotvorného substrátu (nepublikováno). Oba přístupy na lesní půdě i hodnocení zemědělských půd, jakkoli do určité míry stojí na měřených hydropedologických rozborech, neberou žádným způsobem v potaz časové měřítko - tedy dlouhodobé změny hydrologického chování půd např. v důsledku intenzivního hospodaření. Ačkoli je tato problematika $v$ poslední době předmětem diskuzí, není autorům príspěvku známa publikace dokumentující takový vývoj, který by bylo možné vzít do úvahy při definování historických či budoucích scénářu pro hydrologické hodnocení odtoků z povodí. Proto byly v této studii uvažovány půdní charakteristiky v pilotních povodích jako neměnné. Kategorie HSP byly převzaty z [10] kvůli výhodě 100\% pokrytí řešeného území a aktuálnějším informacím pro zemědělskou půdu oproti aktuálně platnému, avšak zastaralému převodníku z HPJ [7].

\section{NÁVRHOVÉ SRÁŽKY}

Zatímco na velkých vodních tocích jsou obvyklou příčinou povodní regionální déletrvající vydatné deště, $v$ prípadě malých povodí to jsou zpravidla srážky přívalové, trvajíci desítky minut až jednotky hodin. Kromě celkového úhrnu přívalové srážky významně ovlivňuje odtokovou odezvu i časový průběh intenzit. Čím vyšší je intenzita, tím vyšší je pravděpodobnost tvorby povrchového odtoku i na propustných půdách. Tento princip, jak známo, metoda SCS-CN zohlednit neumí, při výpočtu objemu odtoku generuje vždy stejné hodnoty nezávisle na průběhu vstupní srážky. Při výpočtu průběhu povodňové viny (a z něj stanovení kulminačního průtoku) např. při spojení CN metody s metodou jednotkového hydrogramu je však zohlednění průběhu srážkových intenzit nezbytné. Připomeňme na tomto místě častou chybu v hydrologické praxi, již je použití tzv. grafické metody, která je obsažena např. v aktuální protierozní metodice [7]. Tato metoda stanovení kulminačního průtoku byla odvozena za předpokladu konkrétního syntetického průběhu intenzit návrhové srážky tzv. návrhového hyetogramu - platného pro část území USA. Na našem území nebyla verifikována, a nelze ji tedy doporučit. První analýzy průběhů intenzit 


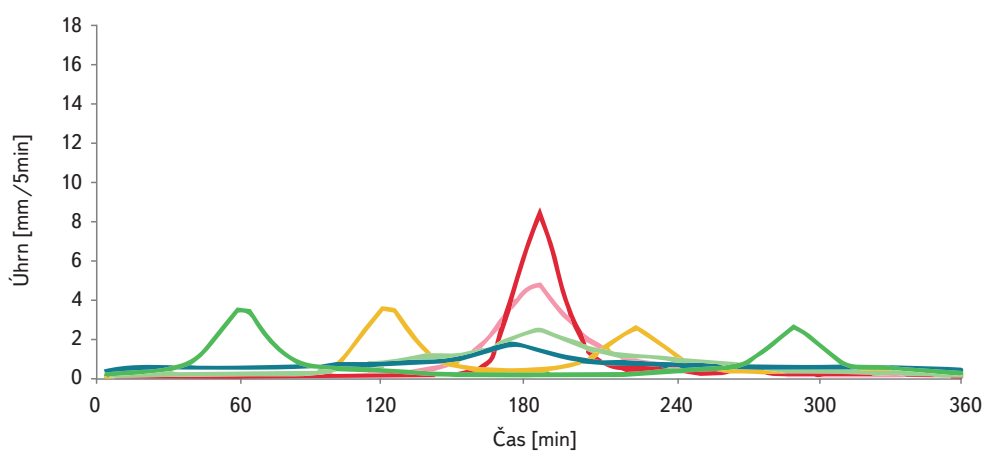

$\operatorname{typ} \mathrm{A}$ typ B typ C typ D typ E typ F

Pravděpodobnosti výskytu návrhových průběhů

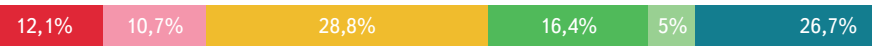

Obr. 6. Návrhové hyetogramy a pravděpodobnost jejich výskytu v povodí Dalejského potoka pro dobu opakování 50 let dle projektu Rain (rain.fsv.cvut.cz) Fig. 6. Design hyetographs with their occurrence frequency in the Dalejsky creek catchment for the rainfall of 50 years return period according to the Rain project (rain.fsv.cvut.cz)

subdenních srážek na území ČR publikovala Kulasová [11] v roce 2012, k dispozici dává (ač pouze graficky, bez tabelovaných hodnot) tři varianty převládajících subdenních hyetogramů v hodinovém kroku. Novější a detailnější alternativu, která byla využita $v$ této studii, popisuje nová metodika pro odvození návrhových srážek na území ČR [12], jež definuje šest typických hyetogramů šestihodinových srážek (obr. 6.) a na přidruženém serveru rain.fsv.cvut.cz poskytuje on-line nástroje pro jejich odvození v libovolném místě ČR. Kromě odhadu návrhového úhrnu zde Ize získat detailní průběh pětiminutových intenzit a relativní četnost výskytu jednotlivých průběhů pro danou dobu opakování. Šestihodinové trvání návrhové srážky bylo zvoleno s ohledem právě na malá povodí a maximální délky přivalových srážek. Odhady úhrnů s dobou opakování 5-100 let na pilotních povodích dle zmíněného serveru shrnuje tab. 2, detaily jejich odvození lze nalézt tamtéž.

Obdobně jako u průtoků vyžadují i statistické údaje o srážkách dlouhou řadu měření. Když pomineme průkopnickou práci Trupla, který zpracoval relativně krátké řady analogických ombrometrických měření na 98 stanicích [13], není známa žádná práce aktualizující charakteristiky subdenní srážky na nyní mnohem delších řadách staničních měření. Detailní prostorové odhady srážek pro

Tab. 2. Návrhové úhrny šestihodinových srážek $v$ pilotních povodich dle serveru rain.fSV.cvut.cz

Tab. 2. Design rainfall totals of 6 hours duration for the study catchments according to rain.fsv.cvut.cz

\section{Návrhový úhrn $(\mathrm{mm})$}

\section{Doba opakování (roky)}

\begin{tabular}{llllll}
\hline Povodí & $\mathbf{5}$ & $\mathbf{1 0}$ & $\mathbf{2 0}$ & $\mathbf{5 0}$ & $\mathbf{1 0 0}$ \\
\hline Dalejský & 31.5 & 36.4 & 41.2 & 47.7 & 52.6 \\
\hline Drahanský & 32.2 & 37.5 & 42.7 & 49.7 & 55.3 \\
\hline Kopaninský & 30.3 & 34.8 & 39.3 & 45.1 & 49.6 \\
\hline Lipanský & 34.2 & 39.9 & 45.6 & 53.3 & 59.2 \\
\hline Motolský & 31.1 & 36 & 40.9 & 47.4 & 52.4 \\
\hline Vinořský & 32.7 & 38.1 & 43.6 & 51 & 56.8
\end{tabular}
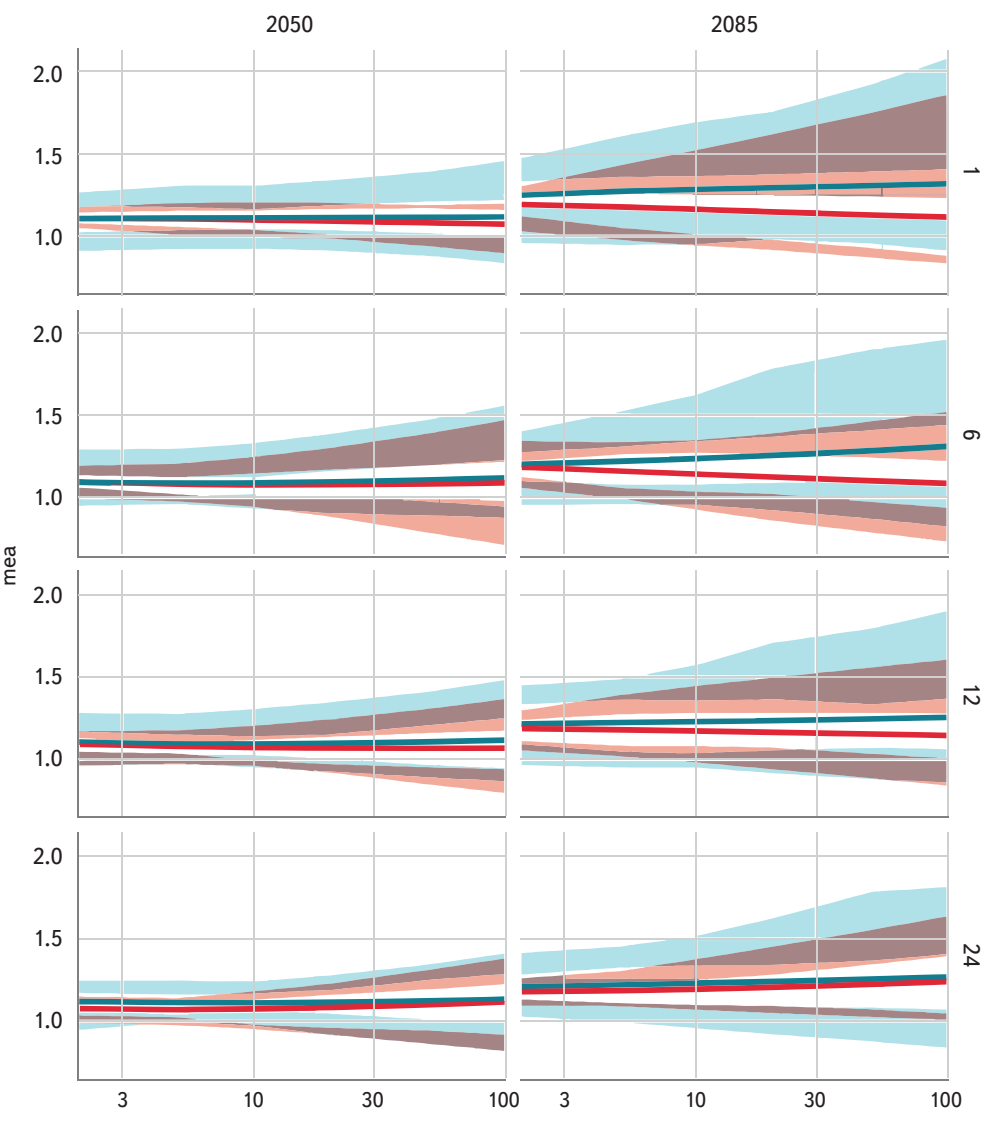

.0 른

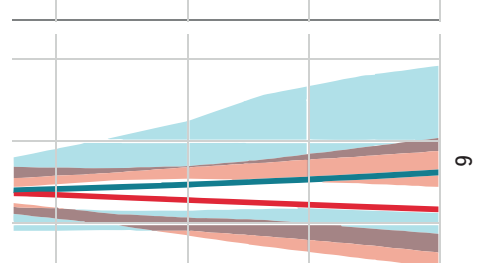

RCP

\section{rсp45}

Obr. 7. Predikované relativní změny (mea, osa y) v intenzitách srážek dle doby opakování (rp, osa x) a délky trvání v hodinách (v rádcích) pro dva budoucí horizonty (ve sloupcích) a dva klimatické scénáře RCP

Fig. 7. Prediction of relative changes in rainfall intensities (mea, $x$-axis) by the return period (rp, x-axis) and time duration in hours (in rows) for two future reference years (in columns) and two RCP scenarios

libovolné místo na území ČR jsou dostupné až v posledních dvaceti letech díky meteorologickým radarům. To je zatím př́liš krátká řada pro analýzu změn srážkových charakteristik, proto byly v této studii použity konstantní hodnoty úhrnů a shodné zastoupení průběhů intenzit ve všech historických scénářích 1920-2012. Pro jednotlivé doby opakování byly na každém povodí zvoleny všechny návrhové hyetogramy, jejichž pravděpodobnost výskytu je vyšší než 15 \%.

První pokusy o projekci budoucích změn charakteristik subdenních srážek na základě klimatických scénářu již existují. Dle výsledků studie [14] se rozptyl predpovídaných změn podle jednotlivých modelů zvyšuje s délkou předpovědního horizontu, což je patrné na obr. 7. Jak ukazují křivky v levém sloupci, pro rok 2050 jsou střední změny intenzit srážek očekávány poměrně konstantní pro všechny doby opakování a délky trvání a nezávislé na scénáři vývoje koncentrací skleníkových plynů RCP. Variabilita předpovědí však roste s rostoucí dobou opakování, jak ukazují obalové křivky 1. a 3. kvantilu na obr. 7, což je třeba vzít v úvahu jako významný zdroj nejistot i pro srážkoodtokové modelování. V této studii jsme pro zachování rozumného počtu výpočetních scénářů uvažovali pouze průměrnou predikovanou změnu ve srážkových intenzitách, která činí +10 \% pro kteroukoli délku trvání. Tento konstantní charakter umožňuje snadnou modifikaci návrhových hyetogramů prostým přenásobením úhrnu v každém časovém kroku konstantou 1,1. 


\section{STAVBA SRÁŽKOODTOKOVÝCH MODELU゚ PILOTNÍCH POVODÍ A VÝPOČETNÍ SCÉNÁŘE}

V prostředí HEC-HMS bylo sestaveno celkem 48 modelů, pro každé z šesti pilotních povodí celkem osm kombinací časového horizontu a scénáre půdního pokryvu. Každé povodí bylo členěno nejméně na tři až šest subpovodí, s výjimkou Motolského potoka, kde bylo kvưli extrémní složitosti a antropogenním změnám hydrografické sítě definováno 11 subpovodí. Jejich hranice byly i v rámci jednoho pilotního povodí mírně proměnlivé $v$ čase podle identifikovaných změn v hydrografické síti (úpravy vodních toků, zaklenutí, stavba suché nádrže) nebo změn ve směrování povrchového odtoku $v$ důsledku stavby významných liniových staveb. Pro každé subpovodí byly z map půdního pokryvu určeny podíly IMP a kombinací těchto map s HSP spočteny průměrné hodnoty $\mathrm{CN}$. Tyto dva parametry determinují v modelu srážkovou ztrátu, tedy v důsledku objem prímého odtoku. Dle metodiky [15] byla z morfologických charakteristik povodí a CN určena odhadovaná doba zpoždění TLAG (viz vztah 15-4a metodiky), jakožto parametr jednotkového hydrogramu, určující spolu s průběhem efektivní srážky rozložení odtoku v čase = průběh odtokového hydrogramu. Potřebné morfologické charakteristiky (průměrný sklon povodí a maximální délka odtokové dráhy) byly odvozeny pro každé subpovodí v prostředí ArcGIS pomocí nástrojů z toolboxu ArcHydro. Pro výpočet postupu a transformace vlny $v$ korytě byla zvolena metoda MuskingumCunge, vyžadující tvar a hydraulické charakteristiky koryta. Tyto parametry byly zadány $v$ několika typizovaných sadách podle charakteru koryta odhadovaného z leteckých snímků, fotografí či osobního terénního průzkumu. V případě Motolského potoka byly zaměřeny objekty suché nádrže Tatra Zličín a definovány charakteristické čáry nádrže pro výpočet transformace odtokových vln. Malé vodní nádrže na všech povodích byly zanedbány. Pro výpočet byly v každém z 48 modelů použity následující meteorologické scénáre.

Kromě základní sady výpočetních scénárư uvedených v tab. 3 byly pro stávající stav půdního pokryvu definovány scénáre na základě pozorovaných intenzivních srážek v roce 2018 pro verifikaci modelů. Pouze pro rok 2018 bylo možné zakoupit od ČHMÚ adjustovaná radarová srážková data v prostorovém rozlišení 1 km² a časovém kroku 10 minut z období od dubna do konce řínna. Vybráno bylo celkem pět intenzivních epizod, které různou měrou zasáhly jednotlivá pilotní povodí. Podle výsledků verifikace popsaných v následující sekci pak byly upraveny všechny modely a spočteny základní sady scénáruu, jejichž výsledky budou diskutovány následně

\section{VERIFIKACE MODELŮ NA POZOROVANÝCH UDÁLOSTECH}

Metoda SCS-CN byla původně odvozena pro malá zemědělská povodí. Teprve později byly vyvinuty postupy pro aplikaci v zastavěných územích, přičemž klíčový problém spočivá ve stanovení tzv. napojených nepropustných ploch. Jedná se o nepropustné plochy prímo odvodňované do hydrografické sítě nebo kanalizačního systému. Jejich podíl se do nástroje HEC-HMS zadává explicitně pro každé subpovodí, při výpočtu pak objem odtoku z této části povodí není redukován metodou SCS-CN a vstupuje do odtokové rutiny celý. Hodnoty napojených nepropustných ploch v praxi nelze zcela exaktně určit, proto byly pro všechny pozorované srážky vypočteny dva krajní scénáře. Ve standardním scénáři (v grafech na obr. 8-11 značeno jako sim.stand) byly jako podíly napojených nepropustných ploch převzaty kompletní podíly IMP odvozené při odvozování Map půdního pokryvu. Druhý, redukovaný scénáŕ (v grafech na obr. 8-11 značeno jako sim.red), uvažuje nulový podíl těchto napojených nepropustných ploch. Redukovaný scénář NEZNAMENÁ, že se v povodí nenachází žádné nepropustné plochy, nebot’ jejich podíl je již zohledněn v hodnotách $C N$, pouze představuje takovou konfiguraci území, ve kterém je veškerý odtok z nepropustných ploch vyústěn na propustné povrchy, nikoli prímo do vodního toku nebo kanalizace. Při zcela exaktním postupu by podíl IMP neměl být zahrnut při výpočtu čísla CN pro zbytek území (propustné a nenapojené nepropustné plochy). Vzhledem ke komplikovanému několikastupňovému určení CN v této studii nebylo provázání těchto dvou parametrů zohledněno, postup podle standardního scénáře by zjevně nadhodnotil objem odtoku.

Verifikace modelů byla provedena prostým kvalitativním porovnáním modelovaných a pozorovaných průtoků. Monitoring hladin (průtoků) byl zrrízen na začátku roku 2018 v profilech identifikovaných jako vhodných během terénního průzkumu, na třech z šesti povodí pak byly pozorovány profily dva. Bohužel monitoring hladin byl zř́zen se zaměěením na nízké průtoky kvưli kvantifikaci bilance povodí, čemuž odpovídal i způsob měření. Zpravidla byly profily osazeny malými měrnými přelivy, často pak v relativně prírodním - a tedy nízkokapacitním - úseku koryta. Na Drahanském a Dalejském potoce tak Ize použít pozorované průtoky pouze $k$ detekci, zda a kdy povodí zareagovalo na prríčinnou srážku, prrípadně srovnávat odezvu standardního a redukovaného modelu. Modelovaný a pozorovaný objem a kulminaci však zde porovnat v žádném případě nelze. Na Lipanském potoce se projevil dopad řady extrémně suchých let, jejichž důsledkem bylo jeho vyschnutí. Pozorování na tomto toku bylo ještě v průběhu roku 2018 zrušeno. Monitoring srážek na pilotních povodích zřizen nebyl, pro verifikaci modelů byly proto použity adjustované radarové snímky srážek v časovém kroku 10 minut, které byly k dispozici od roku 2002 až 2018 pro období od dubna do řína díky projektům QJ1520265 a QK1910029. V modelu byly použity z radarů odvozené průměry pro každé subpovodí $v$ detailním 10minutovém kroku.

Tab. 3. Přehled skupin výpočetnich scénárü pro každé modelové povodí Tab. 3. Overview of computational scenarios groups for each study catchment

Scénáře pro časový horizont Model půdního pokryvu 1920, 1950, 1970, 1990, 2012

Dle Map půdního pokryvu (MPP) 1920-2012

Dle současných odhadi̊ PN6h Nulový vývoj, shodné s MPP 2012

2050-0

MPP 2050, normální vývoj

2050-N

MPP 2050, agresivní vývoj

2050-A
Současné odhady PN6h navýšené o $10 \%$ dle klimatických projekcí

\section{Úhrn 6h srážky Rozložení intenzit}

Návrhové hyetogramy dle současného podílu výskytu nad $15 \%$

Identické průběhy jako výše, intenzity navýšeny o 10 \% dle klimatických projekcí 
Komplikací pro řádnou verifikaci byl krátký průnik období pozorování s obdobím dostupných úhrnů z adjustovaných radarových snímků. Od půli června 2018 (zřízení monitoringu průtoků) do konce října 2018 (konec období dostupných radarových deštových dat) bylo zaznamenáno jen pět intenzivnějších událostí a jejich doba opakování v porovnání s šestihodinovými úhrny neprekkročila úroveň pěti let. U takto nízkých úhrnů je známa poměrně nízká spolehlivost metody SCS-CN [1] a na urbanizovaném povodí se ještě může významně projevovat vliv stokové sítě. Kvůli relativně nízké kapacitě (obvykle je schopna pojmout objem zhruba dvouleté návrhové srážky) zadrží jen omezený podíl odtoku, a její vliv tak s rostoucí dobou opakování príčinné srážky rychle klesá. $\vee$ neposlední řadě se pak některé z pozorovaných událostí skládaly z více dílčích epizod rozdělených v extrémním případě až do tři dnů, takže jejich užití k verifikaci modelu bez komponenty obnovující retenční kapacitu povodí již není korektní. V tomto príspěvku není prostor pro uvedení plného rozsahu verifikace modelů, prezentován bude výběr modelovaných událostí ilustrující specifika některých povodí a jejich odezvy.

\section{VINOŘSKÝ POTOK}

Na Vinořském potoce byla 8. 8. 2018 zaznamenána vůbec nejvydatnější a nejintenzivnější srážka ze všech šesti pozorovaných povodí. Celkový úhrn činil 45 mm, což odpovídá šestihodinové srážce s dobou opakování 20 let, a byl téměř celý koncentrován do jedné hodiny. Modelovaná odezva však zdaleka neodpovídala pozorovaným průtokům standardního ani redukovaného modelu, jak ukazuje obr. 8. Dolní část povodí Vinořského potoka je spíše prírodního charakteru s kaskádou malých vodních nádrží. Ty by mohly vysvětlovat plošší charakter pozorované odtokové vlny oproti modelované, avšak nikoli její dramaticky nižší objem. Horní část povodí je prakticky rovinatá, což vede k velmi nejistému vymezení rozvodnice a značné povrchové retenci. Plochu povodí mohou snadno významně ovlivnit liniové prvky jako silniční komunikace. Podrobný terénní průzkum nebyl $\checkmark$ tomto povodí prováděn, proto byl dodatečně modelován teoretický scénář (sim.spec), v němž byla snížena hodnota CN o 5 bodů a zanedbána nejvýše ležící plochá část povodí. Ani v tomto prípadě se však modelovaná a pozorovaná odezva (viz obr. 8 vpravo dole) nepodobají. Jelikož rok 2018 byl velmi suchý, byly ve specifickém scénári navíc nahrazeny hodnoty $\mathrm{CN}$ pro průměrné vláhové podmínky hodnotami odpovídajícími suchým počátečním podmínkám. Přepočet byl proveden pro každé subpovodí zvlášt podle vztahu uvedeném v metodice [12]. Průměrná hodnota CN1 pro celé povodí ve výši 64,5 dobře odpovídala aktuální denní hodnotě 68 dle indikátoru přivalových povodní modelovaném v celorepublikovém měřítku na ČHMÚ (zdroj: osobní komunikace). Jakkoli je simulovaný odtok (na obr. 8 značeno jako sim.cn1) nejbliže pozorovanému, objem ani kulminace odtoku ani v tomto krajním scénáři nesouhlasí.

Simulace druhé významné srážkoodtokové události z 11.-12. 6. 2018 s úhrnem 37 mm (odpovídá $\mathrm{N}=10$ let) vykazovala podobně špatnou shodu. Ověření modelu tohoto povodí je nutné považovat za neúspěšné a následné modelování historických a budoucích scénářu spíše za určitou formu citlivostní analýzy. Pro získání věrohodných předpovědí by bylo nutné identifikovat př́činy odchylky modelu od pozorované reality.

\section{KOPANINSKÝ POTOK}

Na povodí Kopaninského potoka byla nejintenzivnější srážkoodtoková událost zaznamenána ve dnech 27.-28. 9. 2018 s celkovým úhrnem 19 mm. Jedná se o poměrně nízký úhrn pod hranicí doby opakování dva roky, hodinové úhrny v horní části obr. 9 ukazují, že po většinu doby byla intenzita srážky velmi nízká, takže Ize očekávat tvorbu odtoku spíše z nepropustných a později i ze saturovaných částí povodí.
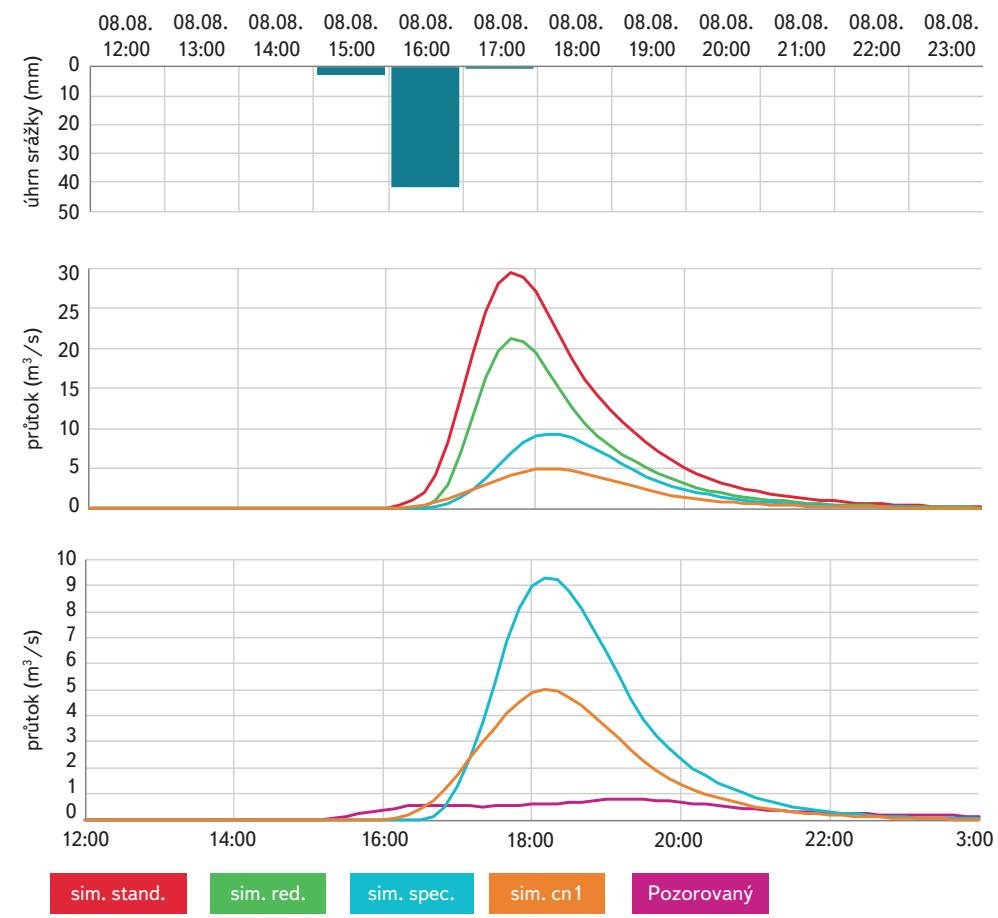

Obr. 8. Srážkoodtoková událost na Vinořském potoce z 8. 8. 2018. Pozorované hodinové srážkové úhrny (nahoře), simulované odtoky ve čtyřech scénářich (uprostřed) a detailní srovnání specifického a „suchého" scénáře s pozorovaným odtokem (dole) Fig. 8. Rainfall-runoff event. in Vinorsky creek catchment on 8. 8. 2018. Hourly rainfall amounts (top), modelled discharges from four scenarios (middle) and observed discharge with two specifically reduced models output in detail (bottom)

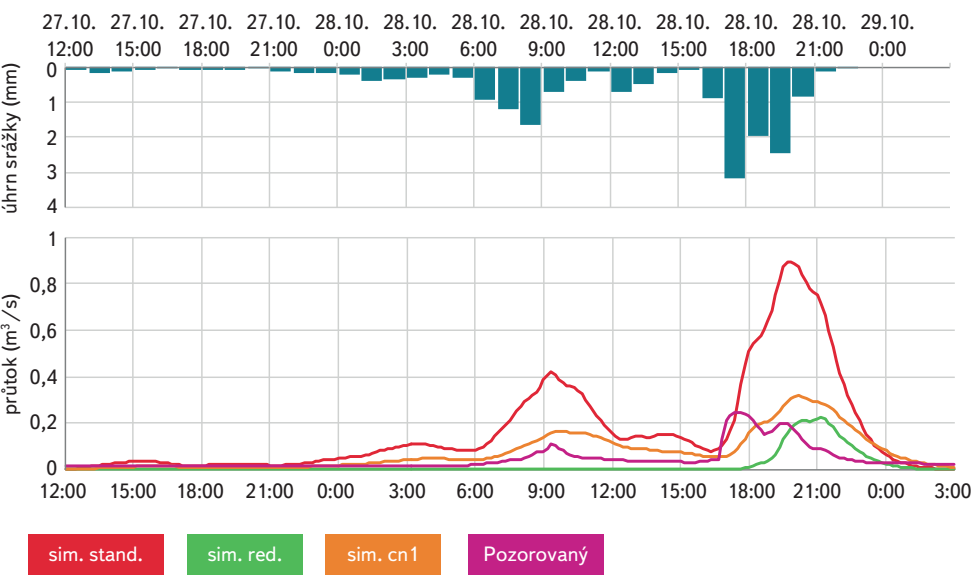

Obr. 9. Srážkoodtoková událost na Kopaninském potoce z 27-28. 8. 2018. Nahoře pozorované hodinové srážkové úhrny, dole pozorovaný (fialově) a modelované odtoky ve standardním (červeně), redukovaném (zeleně) a „suchém” scénáři (oranžově) Fig. 9. Rainfall-runoff event in Kopaninsky creek catchment on 27.-28. 08 2018. Hourly rainfall totals in the top panel, at the bottom observed discharge (violet) compared to modelled discharges from standard (red), reduced (green) and "dry" scenario (orange)

Výsledky modelů tuto hypotézu celkem dobře potvrzují, v redukovaném scénáři (obr. 9 dole) bez prímo napojených nepropustných ploch je odtok generován až v závěrečné části události po vyčerpání počáteční ztráty a v reakci na intenzivnější závěr srážkové události. Ve standardním modelu vede započtení celého podílu nepropustných ploch jako prímo napojených k nadhodnocení objemu odtoku (viz scénáŕ sim.stand na obr. 9). Další testovaný scénár bez napojených nepropustných ploch a s využitím hodnot CN pro suché počáteční 
podmínky (podle hamr.chmi.cz panovalo v daném období v povodí „mírné sucho") dle očekávání nevygeneroval odtok žádný. Tento efekt a odlišné časování kulminací má zřejmě na svědomí fakt, že pozorovaný odtok byl pravděpodobně generován pouze na zpevněných plochách. Kvưli struktuře modelu byl však pro transformaci veškerého odtoku použit jednotkový hydrogram, jehož parametry odpovídají spíše „pomalejším“ průměrným charakteristikám celého povodí. Blíže realitě by bylo modelování složky odtoku z nepropustných ploch s pomocí samostatně definovaného povodí s rychlejší odezvou. Na závěr byl vyhodnocen modifikovaný "suchý" scénáŕ, do něhož byly zadány poloviční podíly nepropustných ploch. Výsledná odtoková odezva (scénář sim.cn1 na obr. 9) je svým charakterem zatím nejbližší pozorované odtokové vlně.

Pozitivním rysem verifikace modelu Kopaninského potoka oproti Vinořskému na této i dalších pozorovaných událostech je rádově bližší objem i kulminace odtoku. Zda je celkově model tohoto povodí schopnější přesnějších predikcí, nelze jednoznačně ríci, pro presnější kalibraci modelu by byla nutná další pozorování extrémnějších srážkoodtokových událostí at' už s ohledem na celkový úhrn, nebo průměrnou srážkovou intenzitu, prípadně méně príznivé počáteční podmínky.

\section{MOTOLSKÝ POTOK}

Verifikace modelu Motolského potoka je nejnáročnější ze všech pilotních povodí, nebot se jedná o povodí těžce antropogenizované. Většina povodí je zastavěna, s výjimkou několika prvních a posledních stovek metrů je tok Motolského potoka zaklenutý a nemalé sídelní celky jsou opatřeny deštovou kanalizací s několika retenčními prvky (DUN). Model povodí se skládal z 11 dílčích povodí s velmi komplikovanými hranicemi, přesto se zřejmě nepodařilo hydrologickou strukturu systému postihnout dostatečně. Nejvýznamnější srážkové události v roce 2018 zasáhly Motolský potok dvakrát krátce po sobě ve dnech 9. a 12. června. Obě srážkové události byly koncentrovány jen do několika hodin a měly úhrn kolem 40 mm, což odpovídá zhruba době opakování 10 let. Při druhé srážce jeden z měrných profilů neměřil, přesto Ize říci, že ani jedna z těchto intenzivních událostí nevedla k odtokům predikovaným modelem. Zvláštní je i skutečnost, že odezva na druhou z událostí byla nižší, přestože povodí bylo v té době více nasycené. Ani vyšší pozorovaná odezva na první událost nedosahuje svým objemem ani kulminací modelovaných hodnot, jak je patrné z obr. 10. Vyšší kulminace byla zaznamenána na horním profilu, který se sice nacházel nad suchou nádrží Tatra Zličín, ale jeho povodí bylo jen asi třetinové oproti dolnímu profilu, kde byly proto očekávány průtoky větší. Zatímco povodňová vina na horním profilu má velmi rychlý nástup a pokles, což odpovídá hydraulicky hladkému - zastavěnému - povodí bez výrazných retenčních prvků, vına na dolním profilu jasně ukazuje efekt deštové kanalizace, kdy ještě několik hodin po konci srážky dochází ke konstantnímu zvýšenému odtoku, jak se postupně prázdnily retenční nádrže. Celkově nízký objem odtoku však existence této infrastruktury vysvětlit nedokáže, jedinou hypotézou kromě chybného měřní je tak odlišná skutečná plocha povodí nebo vliv suchých počátečních podmínek. Horní části povodí zahrnují velmi plochý areál brownfieldu Tatry Zličín a komerční zóny ve Stodůlkách. První z nich je jen částečně zastavěný a mưže disponovat značnou povrchovou retencí, zatímco u druhého areálu není vyloučené částečné svedení odtoků do sousedního povodí. Bez detailního průzkumu odtokových poměrů v těchto oblastech Ize těžko odhadnout skutečnou plochu povodí, modelován byl proto jediný dodatečný scénář sim.cnl, v němž podobně jako v prípadě Vinořského potoka byly použity hodnoty CN odpovídající suchým počátečním podmínkám. Na rozdíl od Vinořského potoka se v tomto případě modelovaný objem odtoku dobře blízí pozorovanému, což potvrzuje hypotézu o vlivu suchých počátečních podmínek. Výrazný rozdíl je však v charakteru odtokové odezvy, což ukazuje pravděpodobně na dominantní podíl odtoku ze zpevněných ploch, který je rychlejší než odtok modelovaný jednotkovým hydrogramem odvozeným spíše pro průměrné charakteristiky povodí.
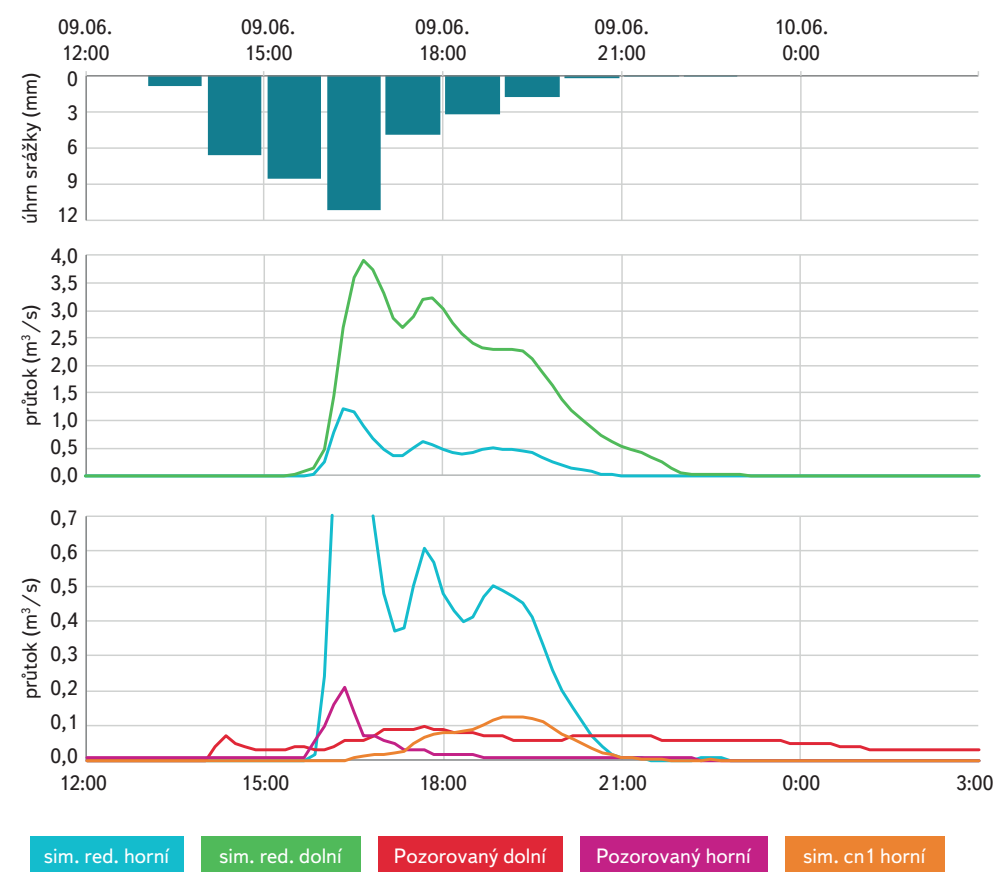

Obr. 10. Pozorovaná srážka (nahoře), simulované odtoky z redukovaných scénářů na obou profilech (uprostřed) a detail srovnání měřených průtoků a dvou simulací z horního profilu (dole) během události z 9. 6. na Motolském potoce

Fig. 10. Hourly rainfall amounts (top), modelled discharges from reduced scenarios in the two monitored profiles (middle) and detailed comparison of two simulated runoff responses in the upstream gage compared to observed runoff in both gages (bottom) during the rainfall-runoff event on 9. 6. in Motolsky creek catchment

Paradoxem pozorování na Motolském potoce je, že nejvyšší zaznamenaný průtok byl registrován na dolním profilu $v$ odezvě na cca dvouhodinovou srážku ze dne 8. 8. s úhrnem necelých $6 \mathrm{~mm}$. Odtoková odezva byla prudká svým nástupem i poklesem. Horní profil nezaznamenal v daném termínu žádnou aktivitu, Ize tedy předpokládat, že se jednalo o odtok z odlehčení deštové kanalizace $v$ areálu nemocnice Motol a přilehlých komunikací, na níž nebyly dohledány žádné retenční prvky. Model tuto srážku reprodukoval překvapivě lépe, když dosáhl asi polovičních hodnot objemu a kulminace odtoku.

Relativně slušně si model Motolského potoka vedl i v prrípadě srážkové epizody z 28.-29. řijna 2018 s úhrnem 20 mm (doba opakování méně než dva roky). Modelované průtoky na horním profilu (obr. 11) svým charakterem slušně vystihují pozorování, přičemž kulminaci odtoku lépe vystihuje redukovaný model bez napojených nepropustných ploch, objem odtoku pak souhlasí lépe u modelu s jejich polovičním podílem (scénář sim.spec; pozor, odlišný od specifického scénáře na Vinořském potoce). Standardní model jednoznačně nadhodnocuje obě povodňové charakteristiky. Dřivější pozorované vrcholy odtoku oproti modelu lze připsat již diskutovanému tvaru jednotkového hydrogramu. $\checkmark$ modelu nelze jednoduše aplikovat jednotkový hydrogram s různými parametry pro zpevněné a nezpevněné části povodí, obě složky odtoku jsou proto transformovány stejně "rychle". Použitá parametrizace hydrogramu odpovídá spíše průměrným charakteristikám povodí, což vede $\mathrm{k}$ podhodnocení rychlosti reakce nepropustných ploch. Na dolním profilu byla shoda modelu a pozorování slabší (není zobrazeno). Rozdíly v objemu a kulminaci byly sice obdobné, ale charakterem byla pozorovaná odezva mnohem pomalejší a poukázala na vliv retenčních prvků, aț už existujících DUN, nebo kaskády tř́ bočních Motolských rybníků. 


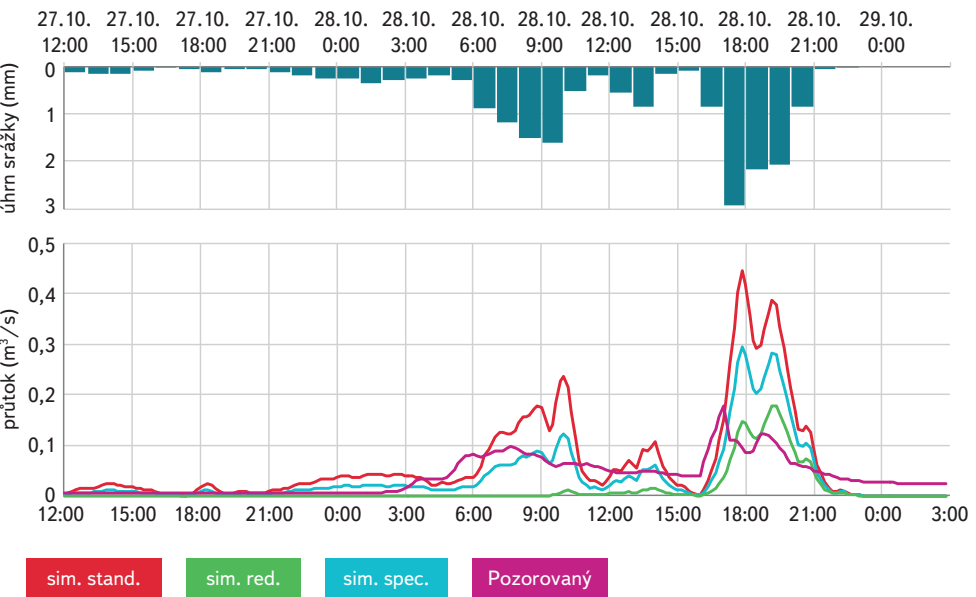

Obr. 11. Pozorovaná srážková událost (nahoře) a srovnání měřených a modelovaných odtoků na horním měrném profilu Motolského potoka během události z 28.-29.10. Fig. 11. Hourly rainfall amounts (top) and observed discharge in the upstream gage compared to modelled discharges during the rainfall-runoff event on 28.-29. 10. in the Motolsky creek catchment

\section{VÝSLEDKY A DISKUZE}

Po zvážení poznatků z verifikace modelů na pozorovaných událostech ve třech pilotních povodích a s cílem nezanášet do modelování další nejistoty bylo všech 48 modelů jednotně modifikováno tak, že podíl napojených nepropustných ploch byl snížen na polovinu celkového zastoupení IMP. Přesnější a individuální nastavení modelů by vyžadovalo více pozorovaných srážkoodtokových událostí, i tak by byla kalibrace parametru IMP platná jen pro současný časový horizont a pro historické a budoucí scénáře by musel být použit odhad.

Po výpočtu všech scénářu byly extrahovány odtokové hydrogramy v závěrovém profilu a vyčísleny odtokové výšky a specifické kulminační odtoky. Na obr. 12 jsou vykresleny odtokové výšky pro všechny uvažované doby opakování a časové horizonty. Pro každý časový horizont je znázorněn pouze jeden bod, nebot všechny scénáře lišíci se jenom průběhem srážky generují stejné objemy odtoku, což je známý nedostatek metody SCS-CN. Ze všech povodí je k vysokým objemům odtoku nejvíce náchylný Dalejský potok, což je důsledek nejvyšších hodnot CN. Následuje Motolský potok, kde k vysokým hodnotám CN přispívá i nejvyšší podíl (napojených) nepropustných ploch. Vysoké hodnoty na Vinořském potoce je třeba brát s opatrností vzhledem k neúspěšné verifikaci jeho modelu na pozorovaných událostech. Nižší odtoky Ize očekávat na povodích Drahanského, Kopaninského a Lipanského potoka. Na všech povodích je patrný očekávaný budoucí nárůst oproti současnosti už u nulového scénáre 2050-0, který uvažuje pouze změnu v klimatických charakteristikách a nikoli plošný rozvoj sídel. Zhruba dvojnásobný nárůst, který způsobuje pouhá změna srážkových úhrnů a intenzit, je patrný u budoucího scénáře normálního vývoje 2050-N. Agresivní scénář 2050-A pak změnu téměř ztrojnásobí, snad s výjimkou Vinořského potoka, kde model překvapivě předvídá spíše pokles oproti normálnímu scénári. To je pravděpodobně anomálie způsobená specifickou predikcí nově urbanizovaných ploch. Na pưvodně hydrologicky nepříznivém úhoru na orné půdě (z hlediska hodnot CN) byl uvažován vznik relativně hydrologicky příznivé zástavby a vyšší množství izolační zeleně podél významných komunikací. To naznačuje možnost kompenzace pokračující urbanizace vhodnou strukturou rozvíjeného území, přesnějši výsledky by však bylo nutné získat detailnějším modelováním a pečlivou tvorbou mapových scénářů. Nevýrazný rozdíl agresivního a normálního scénáře je dále predikován na Motolském potoce, nebot̉ jeho povodí je již nyní silně urbanizované a potenciál pro další rozvoj je zde velmi omezený.

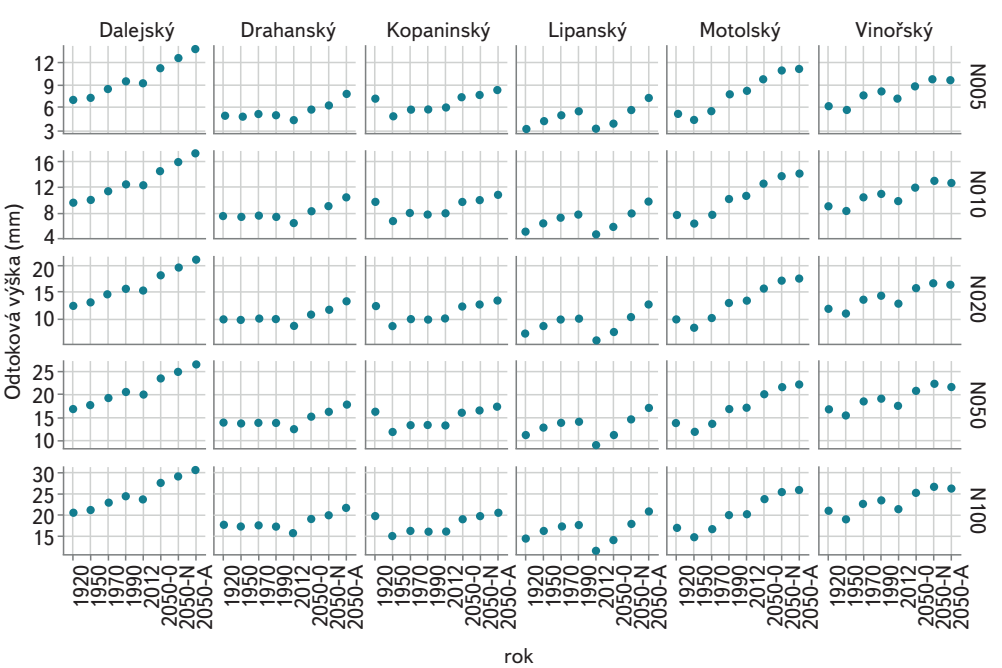

Obr. 12. Vývoj odtokové výšky na pilotních povodích dle doby opakování a časového horizontu

Fig. 12. Modelled runoff volumes in the study catchments by year and return period

Grafy na obr. 13 až 16 ukazují př́klady predikované změny ve specifických kulminačních odtocích na jednotlivých povodích. Kompletní výsledky pro všech šest pilotních povodí lze nalézt na zmíněném mapovém portálu. Středová čára vyjadřuje průměr specifických kulminací, vypočtený je ze všech uvažovaných časových průběhů intenzit a vážený jejich zastoupením $v$ současnosti. Pruhy kolem průměrů pak znázorňují rozsah mezi minimální a maximální simulovanou hodnotou ze všech uvažovaných průběhů, celkově jde tedy o variabilitu způsobenou rozdílným průběhem srážkových intenzit. Z grafů je patrné, že tato variabilita je značná a absolutní velikostí srovnatelná se změnami predikovanými v důsledku pokračující urbanizace povodí. To ukazuje na důležitost dalšího výzkumu průběhů intenzivních srážek a jejich změn $v$ důsledku změn klimatu.
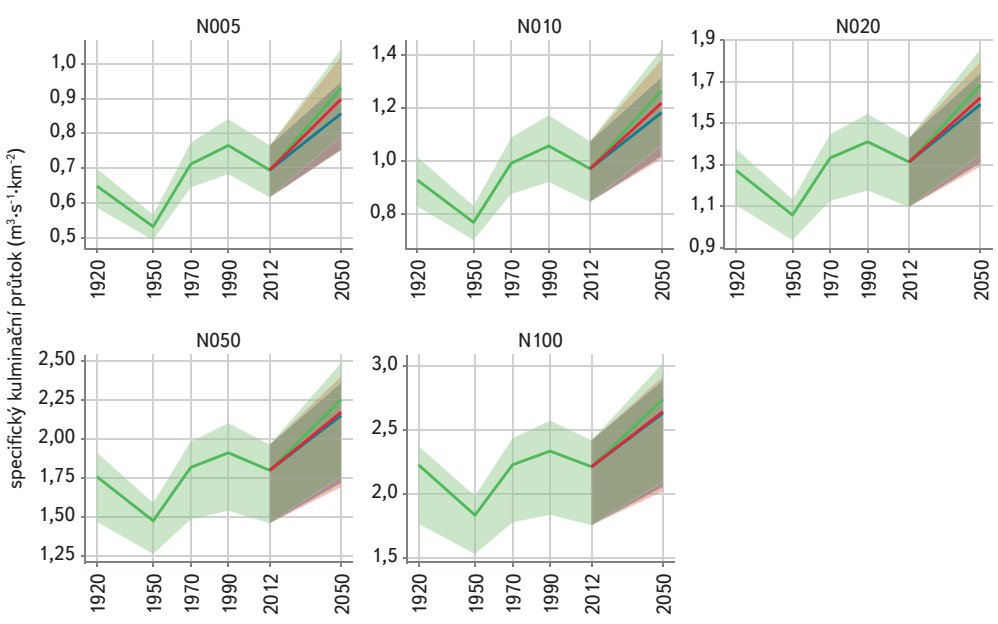

N100

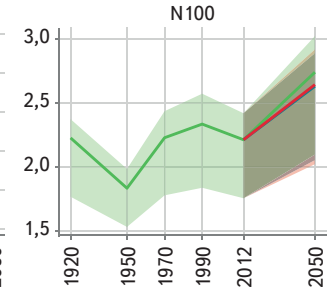

Obr. 13. Vývoj specifických kulminačních odtoků na povodí Vinořského potoka dle doby opakování a časového horizontu. Zeleně historický a normální budoucí vývoj, modře nulový scénár̆, červeně agresivní scénář

Fig. 13. Area-specific peak flows in the Vinorsky stream catchment by year and return period. Historical periods and normal future scenario in green, zero-development scenario in blue, extreme scenario in red 
Zelený pruh na grafech specifických odtoků vyjadřuje historický a normální budoucí vývoj (scénáŕ 2050-N), modrý reprezentuje nulový budoucí vývoj tedy změny vyvolané pouze změnou klimatických charakteristik - a červený pruh agresivní scénář rozvoje sídel. Na všech povodích je dle očekávání predikován nárůst ve všech scénárích, přičemž rozdíly mezi budoucími scénári vývoje sídel klesají s rostoucí dobou opakování srážky. To ukazuje na známý dominantní vliv srážek a slábnoucí schopnost krajiny - urbanizované stejně jako přírodní - zadržet při stejných počátečních podmínkách extrémní úhrny.

Toto jsou však patrně jediné společné rysy pro všechna pilotní povodí, jinak mají na nich modelované specifické kulminace velmi různorodý charakter. Podobně jako u objemů odtoku, paradoxní rozdíly v dopadech budoucích scénářů jsou modelovány na Vinořském potoce (obr. 13), kde agresivní scénář generuje nižší kulminace než scénář normálního vývoje, s rostoucí dobou opakování se dokonce blíží scénáři nulovému. Jak již bylo diskutováno u objemů odtoku, jedná se zřejmě o důsledek specifické podoby mapy budoucího půdního pokryvu. Nepatrné rozdíly mezi budoucími scénáři byly zjištěny v povodi Motolského potoka, kde je prostor pro další růst města již velmi omezený. Vyšší, přesto stále poměrně malé rozdíly predikují různé scénáře vývoje na Dalejském potoce (obr. 14), kde se dočasný pokles kulminací mezi lety 1990-2012 navrací zpět k rostoucímu trendu a jednoznačně dosahuje historicky nejvyšších hodnot. Oproti tomu na Lipanském potoce pouze agresivní scénář pro rok 2050 přesahuje historické maximum roku 1990 (obr. 15), kdy se v povodí nacházely rozlehlé plochy povrchové těžby, orné půdy a staveniště dopravních komunikací, které byly v následujících letech rekultivovány na travnaté a křovinaté plochy. Prostor pro další zástavbu je na tomto povodí značný, a proto jsou i rozdíly mezi budoucími scénáři významné. Zatímco na Lipanském potoce je pokles specifických kulminací mezi lety 1990 a 2012 dán reálnou pozitivní změnou půdního pokryvu, pokles na Motolském potoce mezi roky 1970 a 1990 (obr. 16) je způsoben cílevědomým zásahem člověka do odtokových poměrů - stavbou suché nádrže Tatra Zličín, jejíž efekt v závěrovém profilu vykompenzoval jinak silnou urbanizaci povodí.

Na některých povodích - např. na Vinořském potoce (obr. 13) - je patrný pokles specifických kulminací (a rovněž objemů odtoku) mezi historickými časovými horizonty 1920-1950. Ten Ize připsat možným chybám při náročném

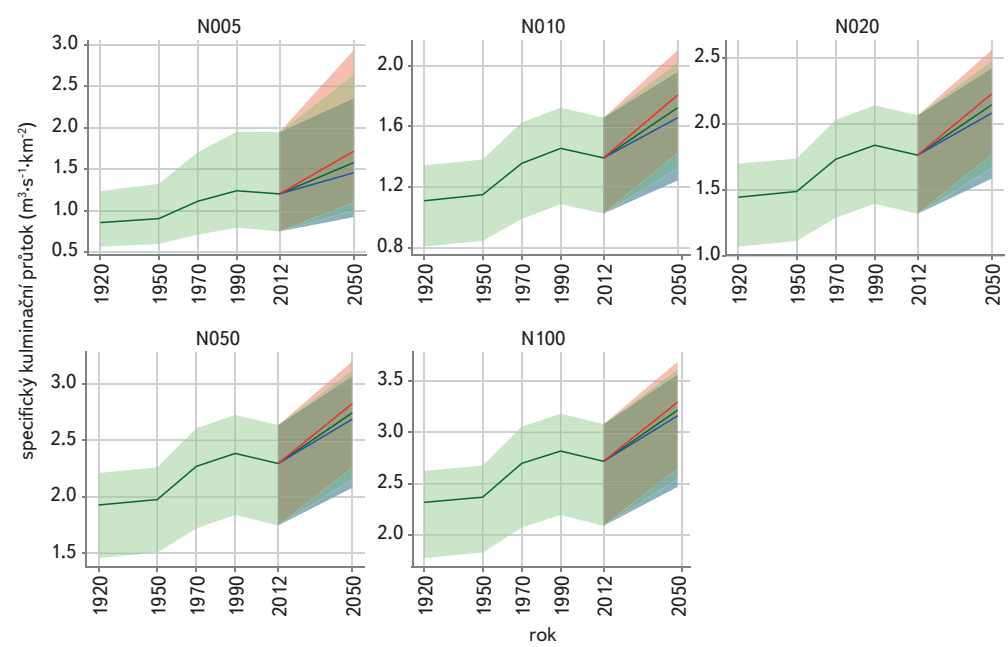

Obr. 14. Vývoj specifických kulminačních odtoků na povodí Dalejského potoka dle doby opakování a časového horizontu. Zeleně historický a normální budoucí vývoj, modře nulový scénář, červeně agresivní scénár̆

Fig. 14. Area-specific peak flows in the Dalejsky stream catchment by year and return period. Historical periods and normal future scenario in green, zero-development scenario in blue, extreme scenario in red určení půdního pokryvu pro rok 1920, pro nějž nebyly k dispozici letecké historické snímky a typ pokryvu byl stanoven na základě kvalitativně odlišných a ne jasně interpretovatelných podkladů.
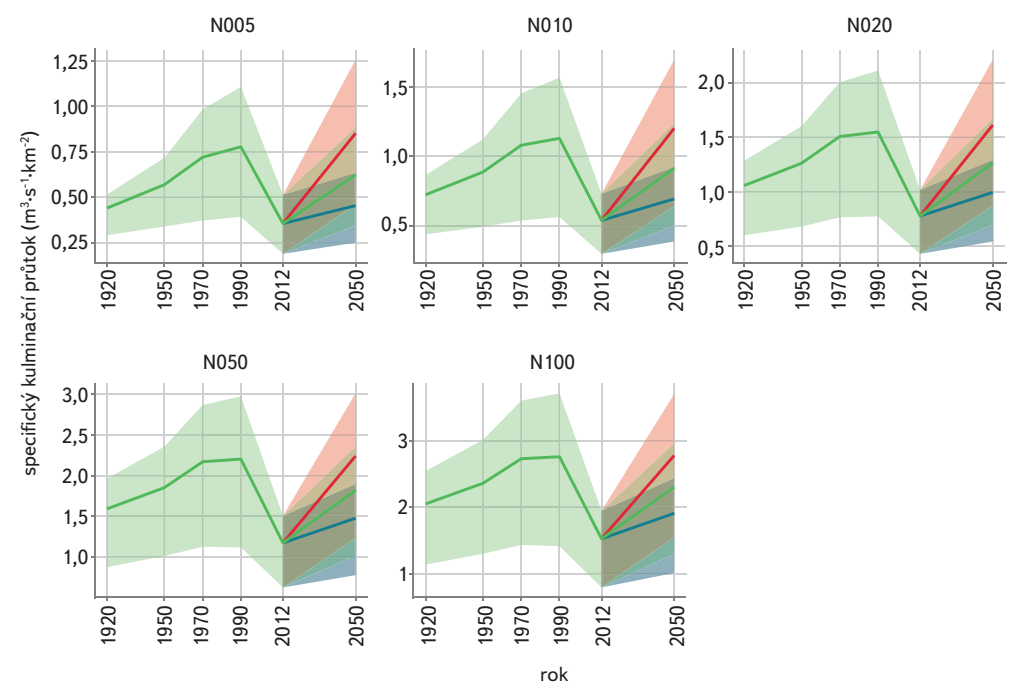

Obr. 15. Vývoj specifických kulminačních odtoků na povodí Lipanského potoka dle doby opakování a časového horizontu. Zeleně historický a normální budoucí vývoj, modře nulový scénár̆, červeně agresivní scénář

Fig. 15. Area-specific peak flows in the Lipansky stream catchment by year and return period. Historical periods and normal future scenario in green, zero-development scenario in blue, extreme scenario in red
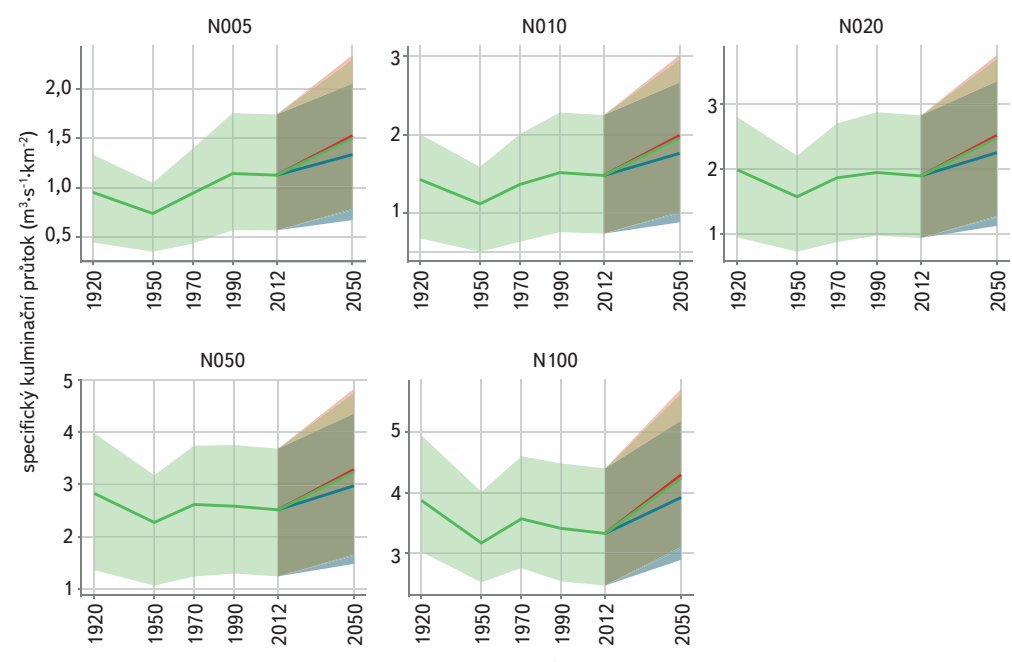

rok

Obr. 16. Vývoj specifických kulminačních odtoků na povodí Motolského potoka dle doby opakování a časového horizontu. Zeleně historický a normální budoucí vývoj, modře nulový scénář, červeně agresivní scénář

Fig. 16. Area-specific peak flows in the Motolsky stream catchment by year and return period. Historical periods and normal future scenario in green, zero-development scenario in blue, extreme scenario in red

\section{ZÁVĚR}

Hodnocení a predikce charakteristik povodňových odtoků na malém urbanizovaném povodí je náročný úkol zejména kvưli absenci přímého měření, a tím nemožnosti kalibrovat srážkoodtokové modely. Jak ukázala prezentovaná studie, jednotky let víceúčelového měření (obzvláště v nevyhovujících profilech 
či konfiguraci měrného objektu pro vysoké vodní stavy) nejsou dostatečné. $\checkmark$ prrípadě existujícího měření je komplikací pro stavbu věrohodného modelu potřeba poměrně detailních vstupů, které jsou ne vždy plně k dispozici. Detailní srážková data Ize dnes s vysokým časovým i prostorovým rozlišením získat ze srážkových radarů. Pozorované zasažení pilotních povodí v této studii a jejich dílčích částí srážkovými událostmi ze stejných termínů s rozdílnými úhrny a intenzitami zdůrazňuje potřebu považovat tento postup dnes již za nutný standard. Informace o hydrotechnické infrastruktuře jsou roztřrištěné a jejich shromažd'ování zdlouhavé. Naštěstí pro studium událostí s dobou opakování nad pět let by zanedbání většiny z nich nemělo vést k významným odchylkám, suché nádrže však zohledněny být musejí. Největší výzvou v této studii byla kvantifikace nepropustných ploch. Potřebné detailní mapové podklady s tímto účelem neexistují, přitom zastoupení nepropustných ploch a zejména určení jejich recipientu - tedy zda jsou prímo napojené na odvodňovací sít, či nikoli se pro hydrologické modelování ukazuje jako naprosto klíčový vstup. Jejich zmapování a klasifikace by byl velmi prínosný počin obecních a státních institucí. Pro hodnocení budoucího vývoje je pak nutné, aby byly dostupné územní plány, pokud možno publikované ve standardizované podobě pro celé území ČR. V této studii bylo nezbytné individuálně kombinovat kvalitativně odlišné podklady HMP a Středočeského kraje, což bylo možné jen díky malému územnímu rozsahu šesti pilotních povodí (z větší části na území jen HMP), v prípadě analýzy celého obvodu Prahy by takový postup nebyl možný.

$\checkmark$ rámci prezentované studie byly vytvořeny vektorové vrstvy historického a projektovaného půdního pokryvu, dostupné jsou ve specializované mapové aplikaci. K těmto vrstvám byly odvozeny hydrologické charakteristiky CN a podíl nepropustných ploch. Kvůli nedostatkům monitoringu (zejména jeho délce) nemohla být provedena kvalitní kalibrace sestavených modelů, proto byly modely jen kvalitativně posouzeny. Lipanský potok vlivem dlouhé suché periody zcela vyschl, měřené průtoky pro verifikaci modelu zde nebyly k dispozici. Model Vinořského potoka se ukázal jako vysoce nadhodnocující pozorované objemy i kulminace odtoků. Dva modely nebyly verifikovány vůbec pro nespolehlivost měření vysokých průtoků a zbylé poukázaly na klíčovou roli tzv. napojených nepropustných ploch. Pro nedostatek presnějších vstupů byl uvažován pro všechny scénáře a všechna povodí shodný podíl 50 \% všech nepropustných ploch jako prímo napojených.

Simulované objemy odtoku vykazují očekávaný rostoucí trend a odpovídají stupni urbanizace povodí. Výsledky nezobrazují nejistoty dané průběhem intenzit př́činné srážky, což plyne z výběru zjednodušené, avšak robustní metody SCS-CN. Specifické kulminační průtoky mají odlišný charakter vývoje prakticky na každém povodí. Shodným rysem je vysoká variabilita daná možnými průběhy srážkových intenzit. Ty byly uvažovány $v$ průběhu let jako neměnné, což podle predikcí dopadů změn klimatu zřejmě neodpovídá realitě a poukazuje na potřebu dalšího výzkumu v této oblasti. Signál změny klimatu - v této studii uvažovaný v jediné variantě navýšením úhrnů všech dob opakování a intenzit v každém bodě návrhového hyetogramu o $10 \%$ - je na vývoji specifických kulminačních průtoků jasně patrný a $v$ absolutních hodnotách srovnatelný s dopady normální uvažované urbanizace. Agresivní scénář vývoje města překoná dopady změny srážkových charakteristik v průměru dvojnásobně. Na modelu Vinořského potoka byl však naznačen i potenciál opačného vývoje, tedy kompenzace klimatické změny uzpůsobením využívání volné krajiny. Rozdíly mezi dopady budoucích scénářů vývoje klesají s rostoucí dobou opakování, což jasně poukazuje na omezení schopnosti prírodě blízkých opatření ovlivňovat povodňové odtoky pouze do dob opakování kolem 20 let, vyšší stupeň ochrany je nutné podpořit vhodnými technickými a organizačními opatřeními.

\section{Poděkování}

Tento článek vznikl za podpory projektu "Analýza adaptačních opatření ke zmirnění dopadů změny klimatu a urbanizace na vodní režim v oblasti vnějši Prahy", č. CZ.07.1.02/0.0/0.0/16-040/0000380, financovaného z Operačního programu Praha pól růstu ČR.

\section{Literatura}

[1] SCS, Tech. Rep. 55: Urban hydrology for small watersheds, 1986

[2] SHERMAN, L., Stream Flow from Rainfall by the Unit Graph Method. Engineering News Record, No. 108, 1932, str. 501-505

[3] USDA NRSC, National Engineering Handbook, chapter 16. Part 630 Hydrology, 2007

[4] SCHARFFENBERG, W., Hydrologic Modeling System HEC-HMS: User's Manual [on-line], Davis: US Army Corps of Engineers, Hydrologic Engineering Center, 2018. Dostupné z: http://www.hec.usace.army. $\mathrm{mil} / \mathrm{software} / \mathrm{hec}$-hms/documentation/HEC-HMS_Users_Manual_4.3.pdf

[5] DEVÁTÝ, J., Klasifikace území pro erozni modely pomocí GIS a verejně dostupných datových zdrojü: disertačni práce, Disertace (PhD.), vedoucí práce Tomáš Dostál, Praha: České vysoké učení technické $\checkmark$ Praze - Fakulta stavební, Katedra hydromeliorací a krajinného inženýrství, 2018

[6] USDA NRSC, National Engineering Handbook, chapter 7. Part 630 Hydrology, 2009

[7] JANEČEK, M., Ochrana zemědělské půdy před erozí - Metodika, Praha: Česká zemědělská univerzita Praha, 2012. ISSN 978-80-87415-42-9

[8] JANDERKOVÁ, J. a kol., Systém komplexního hodnocení pưd 2020. Brno: AOPK ČR, 2000

[9] MACKŮ, J., Problematika stanovení hydrologických skupin půd v lesích. In: Krajinné inženýrství2012. Praha: Ministerstvo zemědělství, 2012, str. 15-22. ISBN 978-80-87384-03-9

[10] VOPRAVIL, J., KHEL, T., HEŘMANOVSKÁ, D., HOLUBíK, O., HUISLOVÁ, Mapové vymezení infiltračních schopností a propustnosti zemëdělských a nezemědělských půd ČR s celorepublikovou územní kategorizací, VúMOP, v. v. i., 2018, Osvědčení č. 8/14130-MZe-2018

[11] KULASOVÁ, B., ŠERCL, P. a BOHÁČ, M., Verifikace metod odvozeni hydrologických podkladů pro posuzování bezpečnosti vodnich děl za povodní, 2004

[12] KAVKA, P., STROUHAL, L., WEYSKRABOVÁ, L., LANDA, M. a MÜLLER, M., Návrhové krátkodobé srážky pro vodohospodářské stavby $\vee$ krajině [on-line], 2019, 27(2), 11-16. Dostupné z: http://www. cmkpu.cz/archiv-casopisu-pozemkove-upravy/

[13] TRUPL, J., Intensity krátkodobých deštưu v povodích Labe, Odry a Moravy. Praha: VúV Praha, 1958

[14] HANEL, M. a kol., Studie klimatických charakteristik pro účely dimenzování prvků PSZ a posouzeni projektových dokumentaci pro realizaci vodohospodářských staveb. ČAST A: Projekce klimatických charakteristik pro účely dimenzováni prvků PSZ. B.m.: Česká zemědělská univerzita v Praze, 2019

[15] USDA NRSC. National Engineering Handbook, chapter 15. Part 630 Hydrology, 2010

\section{Autoři}

Ing. Luděk Strouhal, Ph.D.1

凶ludek.strouhal@vuv.cz ORCID: 0000-0002-3979-4894

Mgr. Petra Šuhájková

凶petra.suhajkova@vuv.cz

ORCID: 0000-0002-7379-3246

\section{Mgr. Ondřej Masák²}

凶masak@poh.cz

' VÚV TGM, v. v. i.

${ }^{2}$ Povodí Ohře, s.p.

Příspěvek prošel lektorským řízením.

DOI: 10.46555/VTEI.2021.01.004 


\section{HISTORY AND FUTURE DEVELOPMENT \\ OF RAINFALL-RUNOFF CHARACTERIS- TICS ON THE OUTSKIRTS OF PRAGUE}

\section{STROUHAL, L.'; SUHAJKOVA, P.'; MASAK, 0. ${ }^{2}$}

${ }^{1}$ T. G. Masaryk Water Research Institute, p. r. i.

${ }^{2}$ Ohře River Basin, state enterprise

Keywords: flood discharge - urbanisation impacts -

historical development - climate change - rainfall-runoff modelling

The article presents a rainfall-runoff study of six catchments on the outskirts of city Prague from 1920 up to today, with a perspective to 2050. Due to a non-existing long-term monitoring the study was achieved by rainfall-runoff modelling using HEC-HMS. The key model inputs were accurate land-cover maps. These were created for each of 5 past periods by partial digitizing, analysis and combination of several historical maps and datasets. Two future land-cover scenarios were proposed. In contrast to the expectations a non-monotonic course of $\mathrm{CN}$ values was discovered, meaning an ambiguous development in runoff volume throughout the assessed history period. In contrast a definite trend in impervious area expansion and their impact was identified. In particular the extent of so called connected impervious areas was found to be the key factor. Unfortunately this parameter is still hard to quantify in the urban areas due to a lack of data detailed enough on this particular aspect of land cover. The analysis of peak flows showed considerable uncertainty due to temporal patterns of rainfall intensity. The range of simulated peaks is comparable with the rainfall volumes increase caused by the expected climate change. The impact of expected continued urbanisation was pronounced especially in the catchments with enough land available for development. Predicted peak flows were found to increase in the future scenarios in all cases, however not always they reached their historical maximum. Differences in future scenarios are tend to decrease with higher return periods. The Vinorsky creak model suggested a potential of climate change (increase in rainfall amounts) compensation by suitable land-cover and land-use management. The overall development of peak flows throughout the history and projected future was found to be specific for each catchment, therefore it is hard to generalize and transfer to another locality. This suggests the necessity to establish a detailed mapping of urban land covers and water structures and individual approach when assessing particular catchment. 